\title{
Arsenic in groundwater in the Bengal Delta Plain : slow poisoning in Bangladesh
}

\author{
Mukherjee, A.B. \\ NRC Research Press \\ 2001
}

Mukherjee, A.B. and Bhattacharya, P. 2001. Arsenic in groundwater in the Bengal Delta

Plain: slow poisoning in Bangladesh. Environmental Reviews 9(3): 189-220.

http://hdl.handle.net/1975/256

Downloaded from Helda, University of Helsinki institutional repository.

This is an electronic reprint of the original article.

This reprint may differ from the original in pagination and typographic detail.

Please cite the original version. 


\title{
Arsenic in groundwater in the Bengal Delta Plain: slow poisoning in Bangladesh
}

\author{
Arun B. Mukherjee and Prosun Bhattacharya
}

\begin{abstract}
The purpose of this paper is to provide an overview of the problems concerning the widespread occurrences of arsenic in groundwater in Bangladesh, a land with enormous resources of precipitation, surface water, and groundwater. Because of the potential risk of microbiological contamination in the surface water, groundwater was relied on as an alternate source of drinking water. Exploitation of groundwater has increased dramatically in Bangladesh since the 1960 s to provide safe water for drinking and to sustain wetland agriculture. The presence of arsenic in the groundwater at elevated concentrations has raised a serious threat to public health in the region. Nearly $60-75$ million people inhabiting a large geographical area are at potential risk of arsenic exposure, and several thousands have already been affected by chronic arsenicosis. The source of arsenic in groundwater is geogenic and restricted within the Holocene sedimentary aquifers. Mobilization of arsenic from the alluvial aquifers is primarily effected through a mechanism of reductive dissolution of the iron oxyhydroxides within the sediments, rather than by the oxidation of pyrite, as has been hypothesized by other workers. The problem is further accentuated by the fact that arsenic is also found at elevated concentrations in vegetables and rice grown in the areas where high-arsenic groundwater is used for irrigation. Dietary habits among the population are also an important pathway for arsenic ingestion. Studies are in progress at national as well as international levels to alleviate the arsenic crisis in Bangladesh. Besides the identification of arsenic-free tubewells in the affected areas for drinking purposes, purification of groundwater at household level by low-cost arsenic removal techniques is suggested. Rehabilitation of the patients with chronic arsenicosis and arsenic cducation programs for rural communities must be addressed urgently by the government of Bangladesh.
\end{abstract}

Key words: arsenic, groundwater, chemistry, redox, causes, effects, Bangladesh.

Résumé : L'objet de cet article est de proposer un panorama des problèmes résultant de la concentration d'arsenic dans les eaux souterraines au Bangladesh, une terre riche en eaux de précipitation, de surface et souterraines. Vu le risque potentiel de contamination microbiologique de l'eau de surface, l'eau de nappes profondes s'est révélée être une alternative pour offrir de l'eau potable. L'exploitation des nappes a augmenté au Bangladesh de manière dramatique à partir des années 60 , afin de fournir une source sûre d'cau potable et de soutenir l'arrosage agricole. La présence d'arsenic à concentration élevée dans les nappes augmente les menaces sérieuses pour la santé publique de la région. Environ 60 à 75 millions

Received November 9, 2000. Accepted July 12, 2001. Published on the NRC Research Press Web site on October 5, 2001 .

A.B. Mukherjee. ${ }^{1}$ Department of Limnology and Environmental Protection, P.O. Box 62, FIN-00014 University of Helsinki, Finland.

P. Bhattacharya. Division of Land and Water Resources, Royal Institute of Technology, SE-100 44 Stockholm, Sweden.

Corresponding author (e-mail: arun.mukherjee(ahelsinki.fi). 
de personnes sont soumises à un risque potentiel de contamination à l'arsenic et plusieurs milliers de personnes ont déjà été affectées par de l'arsenicose chronique. L'arsenic dans les nappes est de source géogénique et se limite aux aquifères sédimentaires dans l'holocène. La mobilisation de l'arsenic des aquifères alluviaux est surtout dû à un mécanisme de dissolution réductive du fer oxyhydroxides dans les sédiments, plutôt que d'une oxydation de la pyrite, hypothèse avancée par d'autres auteurs. Le problème est accentué par lc fait quc l'on trouve de l'arsenic à concentration élevée dans les légumes et dans le riz cultivés dans les zones irriguées avec de l'eau de nappe en teneur ćlévée d'arsenic. Les habitudes diététiques au sein de la population offre aussi une voie importante d'ingestion de l'arsenic. Des études sont en cours, tant au niveau national qu'international, afin de contrôler la crise de l'arsenic au Bangladesh. Par ailleurs, outre l'identification de puits potables dans la zone affectée, la purification de l'eau de sol dans les ménages par des techniques à faible coût est suggérée. La réhabilitation des patients atteints d'arsenicosis chronique, et des programmes d'éducation/sensibilisation à l'arsenic pour les communautés rurales s'imposent d'urgence pour le gouvernement du Bangladesh.

Mots clés: arsenic, eau de nappe, souterraine, redox, causes, cffets, Banglades.

[Traduit par la Rédaction]

\section{Introduction}

Bangladesh is situated in one of the world's largest deltas, located north of the Tropic of Cancer between $20^{\circ} \mathrm{N}$ and $26^{\circ} \mathrm{N}$ and $88^{\circ} \mathrm{E}$ and $92^{\circ} \mathrm{E}$ (Huq and Rahaman 1994). The country has common land borders with India to the north, west, and east and Myanmar to the south-east. To its south is the Bay of Bengal. The total surface area of Bangladesh is about $144000 \mathrm{~km}^{2}$ (55 126 square miles, comparable to the size of Wisconsin, U.S.A.) with a population of more than 120 million. It is one of the most densely populated countries in the world, with a population density estimated at 920 people $\mathrm{km}^{2}$ of land and an annual population growth rate of $1.59 \%$ (1999).

The Bengal Delta Plain (BDP) (also known as the GBM Delta) is drained by three of the major rivers of the world - the Ganges, Brahmaputra, and Meghna (GBM) - which originate in the Himalayas and flow through India, Nepal, and China before flowing into Bangladesh and finally into the Bay of Bengal. Ninety-three percent of surface water in Bangladesh flows from adjoining countries, and precipitation $(1.5-2.5 \mathrm{~m})$ within the country accounts for only the remaining $7 \%$ of freshwater. More than 200 rivers and streams drain through Bangladesh, with a mean annual flow of water of about $38000 \mathrm{~m}^{3} \mathrm{~s}^{-1}$ (Reiman 1993; Huq and Rahaman 1994), carrying over $2.4 \times 10^{9}$ t of sediments each year before discharging finally into the Bay of Bengal (Khan 1994).

According to the statistics presented by Black (1990), there were about 50000 tubewells in the erstwhile East Pakistan (currently Bangladesh) after the political division in the Indian subcontinent in 1947. The source of community water supplies in Dhaka and other regional cities in Bangladesh was groundwater, mainly abstracted from the Dupi Tila aquifer. In other suburban areas and in most rural Bangladesh, surface water (mainly from ponds, locally known as pukur) and water from tubewells and (or) dugwells (shallow wells) were used for drinking and other household purposes. At that time, sufficient groundwater was not abstracted either for drinking purposes or irrigation because of poor infrastructure. Although Bangladesh is known to be a land of rivers, wetlands, and ponds, there has always been a scarcity of reliable fresh surface water free of bacteriogenic contaminants.

Starting in the 1960s, several technological development programs were initiated in Bangladesh by international agencies, including UNICEF, the World Bank, and others. More than 4.5 million shallow and deep tubewells were drilled in the country, with an aim to provide safe drinking water to about $97 \%$ of the population. The technology was economic at a minimal cost of US $\$ 0.30$ per metre (Black 1990). However, no water samples from these wells were analyzed for basic chemical quality. The success of the UNICEF-sponsored tubewell program resulted in reduced infant mortality, and reports on diarrheal dehydration of children under five declined from 250000 in 1983 to 110000 in 1996 (Anon 2000a). But since 1993 this program has become a matter of anxiety because of the manifestations of chronic 
arsenic toxicity among the population in the entire region, resulting from prolonged consumption of groundwater. Recent studies have indicated that chronic arsenic toxicity is caused by consumption of arsenic naturally occurring in groundwater (Chakraborty and Saha 1987; Guha Mazumder et al. 1988; Saha and Chakrabarti 1995; Saha 1995; Mandal et al. 1996; Dhar et al. 1997, Roy Chowdhury et al. 1999).

At the end of the 20th century, the arsenic contamination in groundwater in Bangladesh has been documented as a serious environmental health disaster with severe socioeconomic consequences; a great challenge for the Government of Bangladesh is to provide safe drinking water for the population.

The present paper provides an insight into the historical background to the problem of safe drinking water in Bangladesh from surface water, groundwater, and rainwater sources. It includes special reference to the occurrences and causes of arsenic contamination in groundwater in the BDP aquifers of Bangladesh, which has emerged as a major crisis of the present decade. In addition, social problems due to the presence of arsenic in the drinking water and the present status of technologies available for the removal of arsenic are briefly discussed.

\section{Water resources in Bangladesh}

Bangladesh is essentially a land of rivers, with nearly 54 rivers entering the country. The annual flow of surface water through Bangladesh is estimated to be ca. $1511000 \times 10^{6} \mathrm{~m}^{3}$, of which $360000 \times 10^{6} \mathrm{~m}^{3}$ originates from outside the country (Baurne 1999). The mighty rivers Ganges (Padma) and Bramaputra (Jamuna) contribute $40 \%$ and $50 \%$ of surface water resources. Thus, nearly $90 \%$ of surface water in Bangladesh flows from neighboring countries. Local precipitation ( $1.5-2.5 \mathrm{~m})$ within the country accounts for the rest of the freshwater resources.

\subsection{Surface water}

Two million hectares (e.g., 20\% of the surface area) of Bangladesh is occupied by rivers, canals, and ponds (pukur). Water from these surface water sources is known to be free from natural arsenic, but the water is generally highly polluted and not suitable for drinking purpose without treatment. Industries are few in Bangladesh, mostly situated near big cities and in suburban areas. The surface water bodies, fisheries, and farmlands are, by and large, affected by the untreated effluents from industrial facilities, sewage, atmospheric depositions of toxic particulates, and agrochemicals. Leaching of salts from soils as a result of irrigation is a further problem for surface and groundwater. Surface water treatment plants are, however, expensive and complicated to build and operate in rural areas (Bangladesh Agriculture Sector Review 1989).

\subsection{Precipitation}

The average rainfall in Bangladesh is about $2200 \mathrm{~mm}$, of which $75 \%$ occurs from May to September. The rainwater is free from arsenic and microbiological contamination. Several studies have indicated that it is possible to collect and store rainwater for drinking and household purposes. Because of lack of adequate technology, however, rainwater harvesting is not normally practiced in Bangladesh except in some areas of the Chittagong hill tracts (Chowdhury et al. 1987; BGS/MML 1999a).

\subsection{Groundwater}

Nearly $80 \%$ of the population in Bangladesh lives in rural areas with low socioeconomic status and poor infrastructure. A major challenge has been the provision of safe drinking water in rural sectors. Because of population growth, increased cultivation of high-yield crop varieties to attain self sufficiency in food grain production, and industrial development, the government of Bangladesh recognized the need for groundwater development for irrigation and drinking water supply (Hamid 1993). During the $1980 \mathrm{~s}$, the government of Bangladesh initiated groundwater-based irrigation projects within the National 
Water Plan, with aid from the World Bank and United Nations Development Programme (UNDP), to improve irrigation facilities and meet the rising demand for safe drinking water. The total available groundwater reserve is estimated to be about $63800 \times 10^{6} \mathrm{~m}^{3}$, equivalent to an irrigation potential of $3.9 \times 10^{6}$ ha. At present, $60 \%$ of the irrigated area is served by groundwater, with the remaining $40 \%$ served by surface water and seasonal rainfall. Groundwater has been a reliable source of water for irrigation and for potable water for a large fraction of the population in rural Bangladesh for the last 30 years. The number of domestic hand pumps now exceeds that of irrigation wells in Bangladesh (Pitman 1993).

Because of increased withdrawal of groundwater in rural communities for drinking and irrigation purposes, especially for winter paddy cultivation, the problem of arsenic contamination has become acute in the BDP (Bhattacharya et al. 1997; Dhar et al. 1997). In recent years, the presence of arsenic at concentrations above the permissible drinking water standard $\left(0.01 \mathrm{mg} \mathrm{L}^{-1}\right.$, WHO, and $0.05 \mathrm{mg} \mathrm{L}^{-1}$, Bangladesh standard) has been reported in groundwater (Fig. 1) over an area of nearly $118012 \mathrm{~km}^{2}$ in 52 districts of Bangladesh (Karim 2000).

\section{Distribution of arsenic in nature}

\subsection{Abundance of arsenic in the crust of the earth and in sediments}

Arsenic is a natural constituent of the crust of the earth, ranking 20th in abundance in relation to other elements. It is a metalloid and a member of the nitrogen family. It is tasteless and odorless. Concentrations of arsenic in major types of rocks range between 0.5 and $2.5 \mu \mathrm{g} \mathrm{g}^{-1}$ (NAS 1977; Taylor and McLenan 1985; Kabata-Pendais and Pendais 1992), and its concentration in soils depends on parent rock characteristics, anthropogenic activities, climate, organic and inorganic components, and redox potential of the soil (Yan-Chu 1994). Arsenic has a long history of human use because of its toxic and medical properties. In the orient, arsenical compounds were used in medicine 2000-3000 years ago (Ferguson and Gavis 1972).

Arsenic is concentrated in minerals, either as arsenides of copper, lead, silver, or gold or as sulfides and sulfates. Major arsenic-containing primary minerals are arsenopyrite ( $\mathrm{FeAsS})$, realgar $\left(\mathrm{As}_{4} \mathrm{~S}_{4}\right)$, and orpiment $\left(\mathrm{As}_{2} \mathrm{~S}_{3}\right)$. Arsenic usually occurs in oxidized forms in sediments. In sandstones, the arsenic content varies from 0.6 to $120 \mathrm{mg} \mathrm{kg}^{-1}$, whereas in shales and clay formations the concentrations may be as high as $490 \mathrm{mg} \mathrm{kg}^{-1}$ (NAS 1977). This higher value of arsenic in shales and clays is due to its accumulation during weathering and translocation in colloid fractions (Yan-Chu 1994). Typical concentration ranges of arsenic in crustal rocks are presented in Table 1. Concentration of arsenic varies enormously among coals from different sources, and its concentration range worldwide is reported to be between 0.5 and $80 \mathrm{mg} \mathrm{kg}^{-1}$ (average $10 \mathrm{mg} \mathrm{kg}^{-1}$ ) (Clarke and Sloss 1992), although higher values have been reported occasionally.

In aquatic environments, inorganic arsenic occurs as oxyanions, namely in pentavalent arsenate $\left(\mathrm{H}_{n} \mathrm{AsO}_{4}{ }^{n-3}\right)$ and trivalent arsenite $\left(\mathrm{H}_{n} \mathrm{AsO}_{3}{ }^{n-3}\right)$ forms. Arsenate usually predominates under oxidizing conditions (Robertson 1989), whereas arsenite is predominant under reducing conditions, especially in sulfidic and methanic water (Korte and Fermando 1991; Pokrovski et al. 1996). Arsenate is commonly adsorbed onto the surface of iron, aluminum, and manganese oxides under an oxidizing environment and hence is immobile. Under reducing conditions transformation of arsenate into arsenite facilitates mobilization of arsenic from the sediments to the groundwater. However, the solubilities of arsenic species play an important role in controlling its pathways in the environment (Thornton 1999).

\subsection{Pathways of arsenic emission}

Arsenic input into the ecosystem can be divided into two categories: natural and anthropogenic emissions. There are several reports that cover both categories of arsenic emissions to the atmosphere on global, regional, and local scales (Nraigu and Pacyna 1988; Nriagu 1989; Pacyna 1996, 1998). Once 
Fig. 1. Percentage of wells in shallow aquifers $(<150 \mathrm{~m})$ with arsenic concentration exceeds the drinking water standard (50 $\mu \mathrm{g} \mathrm{mg} \mathrm{L}^{-1}$ ) (redrawn from BGS/MML 1999a).

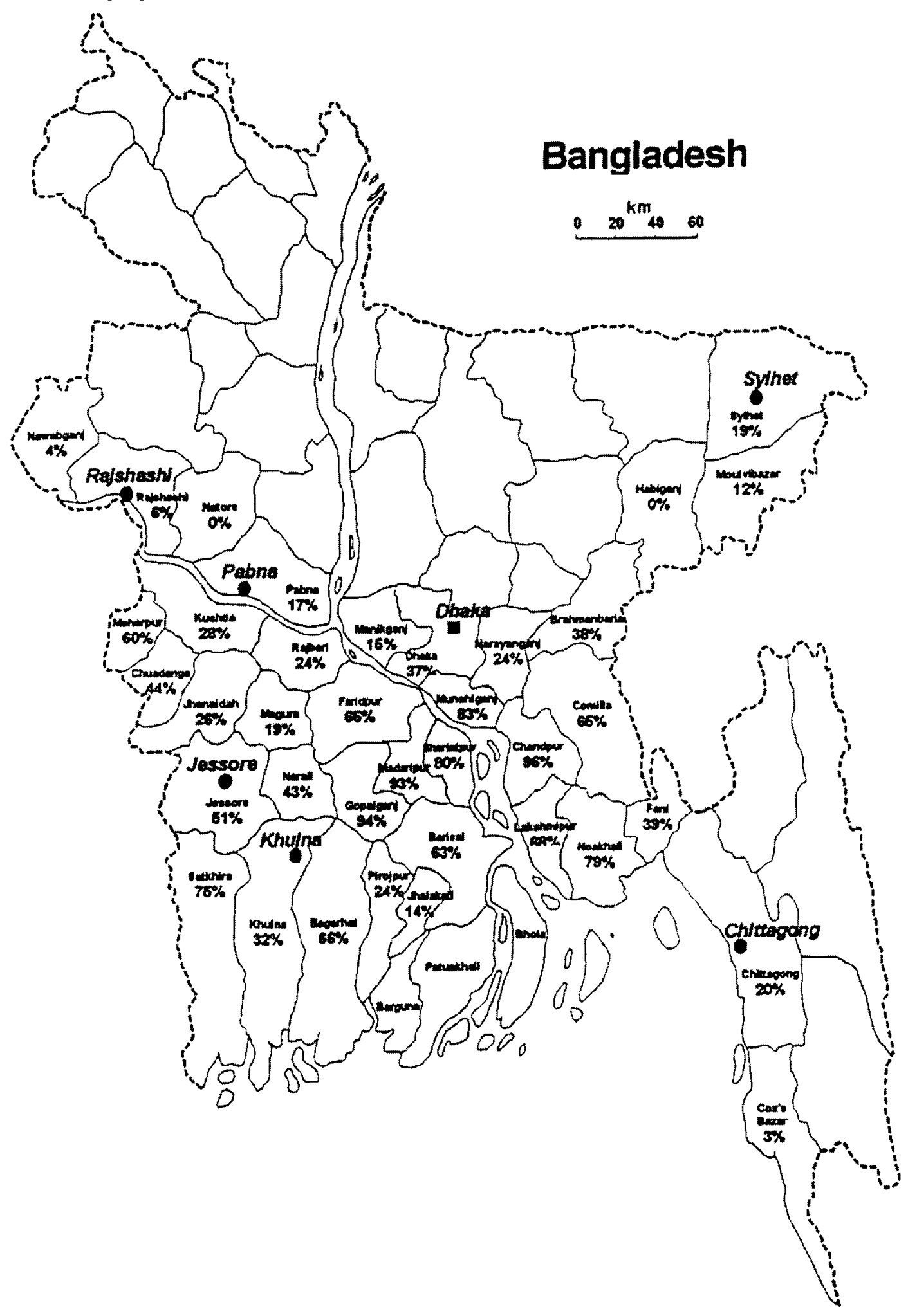


Table 1. Natural abundance of arsenic in crustal materials (Jacks and Bhattacharya 1998).

\begin{tabular}{ll}
\hline Rock type & Abundance $\left(\mathrm{mg} \mathrm{kg}^{-1}\right)$ \\
\hline Igneous rocks & $0.3-16$ \\
Ultrabasics & $0.06-113$ \\
Basalts & $0.5-5.8$ \\
Andesites & $0.2-13.8$ \\
Granites/silicic volcanics & \\
Sedimentary rocks & $0.3-490$ \\
Shales and clays & $0.4-188$ \\
Phosphoritcs & $0.6-120$ \\
Sandstones & $0.1-20$ \\
Limestones & $1.0-1500$ \\
Coal & $16-340$ \\
Peat & \\
\hline
\end{tabular}

it is introduced into the atmosphere, arsenic can circulate for a long period of time before transfer to a permanent sink. Soluble (reduced) forms of arsenic in water tend to be quite mobile, whereas less soluble forms tend to adsorb onto sediments and clays or other mineral soil components. Microbial activity in soils, sediments, and water produce the methylated forms of arsenic that are volatile in nature and can re-enter the atmosphere and ultimately change back into inorganic forms. ${ }^{2}$

\subsubsection{Industrial emissions}

Information on anthropogenic release of arsenic to the environment of Bangladesh is not available. There are about 30000 industrial facilities in and around the major cities where soil arsenic concentrations mostly range between 2.13 and $4.27 \mathrm{mg} \mathrm{kg}^{-1}$. However, in the vicinity of industrial sites some hot spots with soil arsenic concentrations as high as $5020 \mathrm{mg} \mathrm{kg}^{-1}$ have been recorded (Ullah et al. 1999). As for the energy sector, total production was about 22.44 Mtoe (million tonnes of oil equivalent) from oil, natural gas, hydroelectricity, and combustible renewable wastes. In Bangladesh, there are no coal-fired thermal power plants. Diffuse emission of arsenic is expected to occur during the burning of wastes, jute, and oil and also from other high temperature processes.

In developed and developing regions industrial sources of arsenic generally include coal-fired power plants, smelting and melting of metals, incinerations of wastes, and the use of fertilizers, pesticides, chemicals, and solvents. Because of strict regulation, better abatement technologies, and process change, arsenic emissions to the atmosphere of Europe were reduced from $11500 \mathrm{t}$ per year (in the period 1960 1965) to $4570 \mathrm{t}$ in 1985 (Pacyna 1996; UN/ECE 1999). Future estimated projected arsenic emissions for Europe to be about $1900 \mathrm{t}$ in 2000 (Pacyna 1998).

\subsubsection{Natural sources}

Natural emissions of heavy metals are affected by interaction of the atmosphere with the lithosphere. oceans, and cosmic space. In view of the numerous different pathways for the release of arsenic to the atmosphere, it is rather difficult to estimate the amount of this metalloid released, although Nriagu (1989) estimated global natural emissions of arsenic for 1983 to be $12000 \mathrm{t}$ (Ryaboshapko ct al. 1999).

Weathering and leaching of arsenic-rich geological formations and mining wastes result in elevated concentrations of arsenic in natural waters in several parts of the world. The risk of arsenic contamination

2 Ren, X. 1993. Study of environmental arsenic pollution from smelter and human exposure level in Yuman province. Paper presented at National Symposium on Environmental Criteria, Nanking, China, May. 
is, however, much higher in groundwater than in surface water such as rivers, lakes, and reservoirs. Incidences of natural occurrence of arsenic in groundwater $\left(>10 \mu \mathrm{g} \mathrm{L}^{-1}\right)$ are reported from scveral countries in the world, namely the United States (Welch et al. 2000), Canada (Grantham and Jones 1977), Argentina (Smedley et al. 1998; Bundschuh et al. 2000), Mexico (Cebrian et al. 1983; Armienta et al. 1995, 1997, 2000; Rodriguez et al. 2000), Chile (Borgoño and Greiber 1972; Borgoño et al. 1977), Ghana (Smedley 1996), Hungary (Varsanáyi et al. 1991), and Finland (Idman 1996). In Asia, arsenic-laden groundwater is reported in Taiwan (Lu 1990; Chen et al. 1994), China (Lianfang and Jianzhong 1994; Luo et al. 1997), Japan (Terade et al. 1960), southern Thailand (Choprapawon and Rodcline 1997), West Bengal, India (PHED 1991, 1993; Chatterjee et al. 1995; Bagla and Kaiser 1996: Bhattacharya et al. 1997), and most recently from Bangladesh (Dhar et al. 1997; Nickson et al. 1998; von Brömssen 1999). Table 2 summarizes the salient aspects of the distribution, concentration, and the possible mechanism for the release of arsenic in groundwater in a few affected countries.

\section{Arsenic in the environment of Bangladesh}

\subsection{Review of the causes of arsenic contamination}

Several factors have been assumed to have caused the substantial input of arsenic in the aquatic environment of Bangladesh (BGS/MML 1999a). These are (i) wooden poles treated with arsenic-based compounds supporting electric wires; (ii) uses of pesticides and chemical fertilizers; (iii) relcase of untreated effluent from facilities; and (iv) arsenic accumulated (enriched) in sediments by geological processes. Among the factors listed above, the first three are not directly responsible for the prevalence of widespread arsenic contamination in groundwater. However, these sources may lead to considerable contamination of soil and groundwater system elsewhere (Welch et al. 2000; Bhattacharya et al. 2001). Input of arsenic to agricultural soils may have been caused by the application of monosodium methanearsonate (MSMA) and lead arsenate $\left(\mathrm{PbHAsO}_{4}\right)$ as pesticides prior to the introduction of DDT (Welch et al. 2000). The most acceptable hypothesis, according to the present status of our knowledge, is that the cause of widespread arsenic contamination in the groundwater of BDP in Bangladesh is geological. Arsenic in the groundwater is released primarily from the sediments deposited during the Holocene period (Bhattacharya et al. 1998a, 1999a; BGS/MML 1999a).

\subsection{Nature of the alluvial sediments in the Bengal Delta Plain}

The sedimentary succession in the BDP consists of a thick sequence of sediments deposited by the Ganges, Brahmaputra, and Meghna rivers and their tributaries and distributaries (Bhattacharya et al. 1997, 1999a). The pool of arsenic-contaminated groundwater is hosted by the sediments deposited by the meandering river channels during the late Quaternary or the Holocene age. Lithology of these sedimentary successions include sand, representing the channel facies, and the overbank facics, comprising predominantly silt and clay, and exhibit a typical fining upward character (Bhattacharya et al. 1997, 1999a; Ahmed 1999). The fine-grained overbank facies are rich in organic matter (Nickson et al. 1998; Bhattacharya et al. 1999a; Mazumdar 2000). A typical sedimentary succession with stacks of fining upward sequences in Tala, Satkhira district in southwestern Bangladesh, is presented in Fig. 2.

The arsenic in these Holocene BDP sediments can be attributed to the parent rocks rich in arsenic from both the Himalayas and the highlands in the neighboring areas. Several isolated high arsenic geological domains are recognized that can be potential sources of the arseniferous sediments (BGS/MML 1999b; Bhattacharya et al. 1999a; Acharyya et al. 1999). These include (i) Samthan Hill near Darjeeling, West Bengal, India, sulphide minerals with arsenic concentration as high as $7.5 \% ;(i i)$ arsenic-bearing nickel ores at Singbhum in Bihar, India; (iii) pyrite and chalcopyrite occurring widely in the granites and granitoid rocks of the Chottonagpur and Shillong Hills, India; $(i v)$ iron ore deposits in eastern India are a major source of arsenic from the upper to the lower Ganges Bengal basin; $(v)$ Gondwana coal 


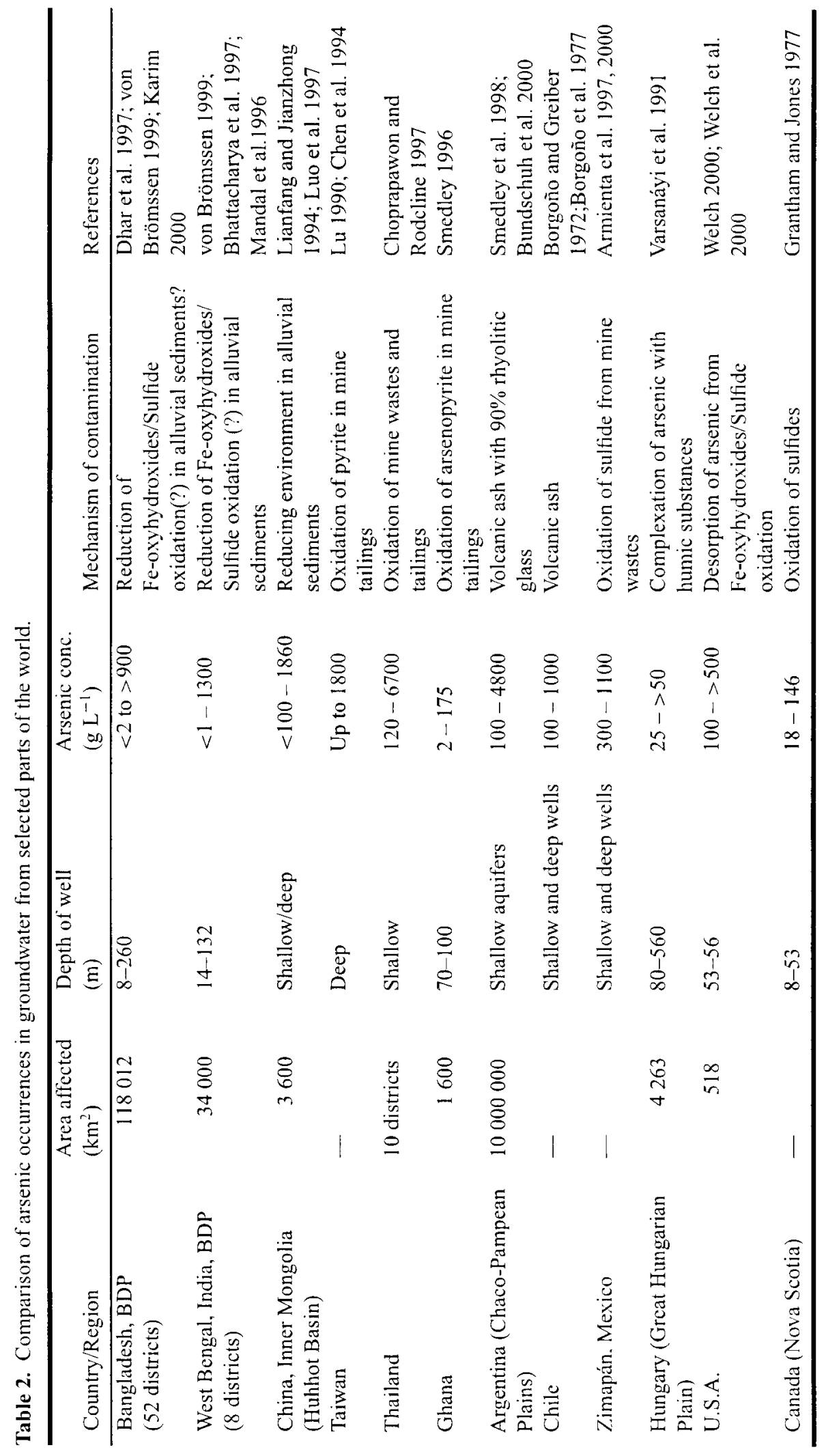


Fig. 2. Succession of Holocene aquifer sediments with fining upward character of the deposits of meandering channels at Tala, Satkhira district in southwestern Bangladesh (redrawn from Mazumdar 2000).

\section{Depth}

$\begin{array}{ll}0.0-2.5 \mathrm{~m} & \text { Silt } \\ 2.5-4.0 \mathrm{~m} & \text { Silty clay } \\ 4.0-7.5 \mathrm{~m} & \text { Very fine sand } \\ 7.5-11.5 \mathrm{~m} & \text { Very fine sand with intercalated sitt } \\ 11.5-15.0 \mathrm{~m} & \text { Silt/clay intercalation }\end{array}$

15.0-22.0 $\mathrm{m}$ Very fine sand/silt intercalation

22.0-27.0 m Fine sand

27.0-30.0 $\mathrm{m}$ Silty clay with organic matter

30.0-39.0 $\mathrm{m}$ Silt/Nery fine sand

39.0-45.0 $\mathrm{m}$ Fine sand with mica

45.0-65.0 $\mathrm{m}$ Fine sand -silt intercalation with organic matter

\section{Lithology}

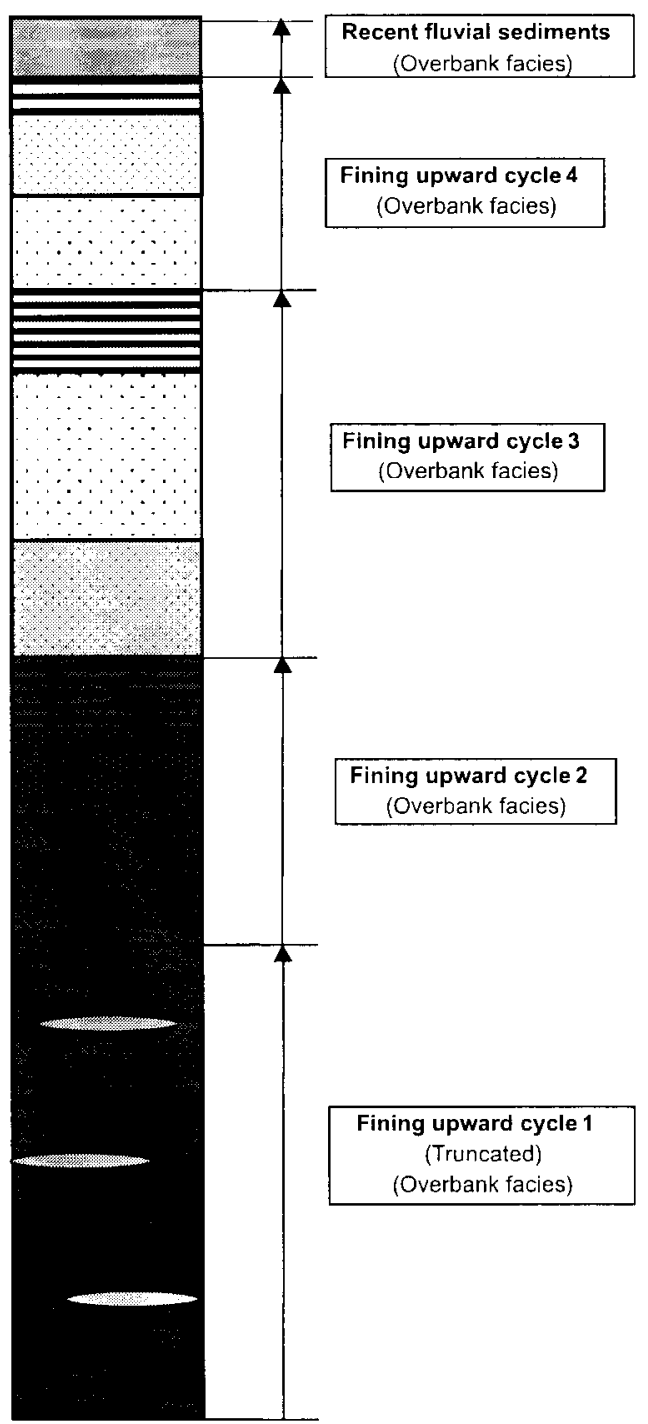

contains significant quantities of arsenic; $(v i)$ volcanic terrain in Rajmahal (district Bihar), India; and (vii) the arc of the ultramafic suite of rocks occurring along the Indus Suture Zone. Another speculation about the potential source of arsenic is the Toba Ash, which resulted from the volcanic eruptions in the Indonesian archipelago during the Quarternary period. ${ }^{3}$

Thus the arsenic in the BDP sediments can be attributed to source terrains in the close proximity of the depositional basin. Arsenic liberated because of the oxidation of the primary arsenic-bearing sulfide mincrals is brought to the BDP by the phases adsorbed onto suspended particulates, where arsenic is mostly adsorbed and co-precipitated with secondary Fe, Al, and Mn phases in the form of As(V)

3 Aftab Alam Khan, Bangladesh, personal communication. 
Fig. 3. Eh-pH diagram showing the thermodynamic stability fields of trivalent $\mathrm{As}\left(\mathrm{H}_{3} \mathrm{AsO}_{3}\right.$ as unchanged species) and pentavalent $\mathrm{As}\left(\mathrm{H}_{2} \mathrm{AsO}_{4}{ }^{2-}\right.$ and $\mathrm{H}_{2} \mathrm{AsO}_{4}{ }^{-}$as the protonated species) along with the plot for the water samples from Bangladesh.

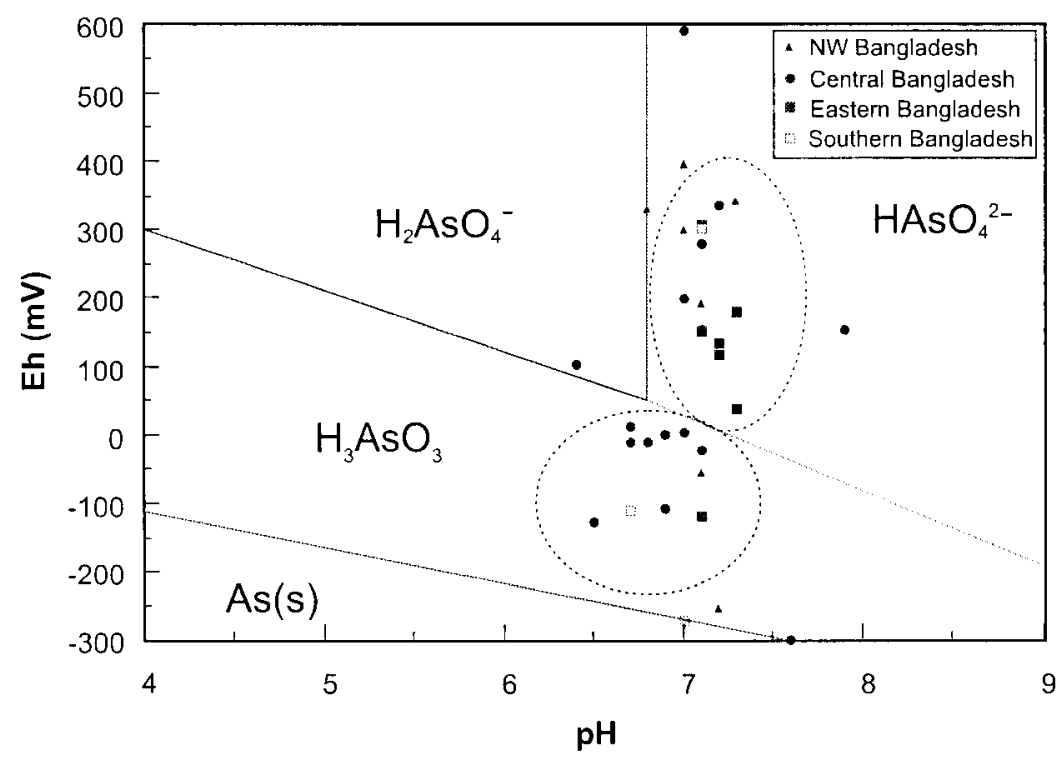

and finally deposited in the delta depending on the topography of the basin (Bagla and Kaiser 1996; Bhattacharya et al. 1997; Dhar et al. 1997; Nickson et al. 1998, 2000; Sahu et al. 2000).

\subsection{Geochemical characteristics of arsenic in the Bengal Delta Plain groundwater environment}

\subsubsection{Groundwater chemistry and relation to arsenic}

Groundwater $\mathrm{pH}$ is predominantly near neutral to slightly alkaline (pH 6.5-7.6). The Eh values vary between +594 and $-444 \mathrm{mV}$, which suggests mildly oxidizing to moderate/strong reducing nature of groundwater environment in the BDP aquifers. The data plotted in an Eh-pH diagram (Fig. 3) indicates two clusters on the thermodynamic stability fields of trivalent $\mathrm{As}\left(\mathrm{H}_{3} \mathrm{AsO}_{3}{ }^{\circ}\right.$ as unchanged species) as well as the field of pentavalent $\mathrm{As}\left(\mathrm{HAsO}_{4}{ }^{2-}\right.$ as the protonated species). The groundwater types are generally $\mathrm{Ca}-\mathrm{HCO}_{3}$ or $\mathrm{Ca}-\mathrm{Mg}-\mathrm{HCO}_{3}$ type, although $\mathrm{Ca}-\mathrm{Na}-\mathrm{HCO}_{3}$ type and $\mathrm{Na}-\mathrm{Cl}$ type water are also present locally in some areas (Bhattacharya et al. 1998b, 1999b; Ahmed 1999).

Major ion chemistry in groundwater is dominated by bicarbonate (320-600 $\left.\mathrm{mg} \mathrm{L}^{-1}\right)$ and shows an apparent depth and lithological control (Bhattacharya et al. 2001; Routh et al. 2000). Sulfate concentrations are by and large low $\left(\leq 3 \mathrm{mg} \mathrm{L}^{-1}\right)$ except for one location in Munshiganj district where a sulfate concentration was found to be high $\left(8.5 \mathrm{mg} \mathrm{L}^{-1}\right)$. Nitrate concentrations are also low in the groundwater samples $\left(\leq 0.22 \mathrm{mg} \mathrm{L}^{-1}\right)$. On the other hand, phosphate concentrations $\left(0.05-8.75 \mathrm{mg} \mathrm{L}^{-1}\right)$ are high in these analyzed groundwater samples.

Considerable variation in the concentration of total $\mathrm{Fe}\left(\mathrm{Fe}_{\mathrm{tot}}\right)$ is noted for the BDP groundwater of Bangladesh $\left(0.4\right.$ to $\left.15.7 \mathrm{mg} \mathrm{L}{ }^{-1}\right)$. Total arsenic $\left(\mathrm{As}_{\text {tot }}\right)$ concentration in the analyzed wells varies between 2.5 and $846 \mu \mathrm{g} \mathrm{L}^{-1}$. Arsenic(III) is the dominant species and accounts for about $67-99 \%$ of the total arsenic in most water samples. In certain wells, however, arsenic(V) dominates. Arsenic concentrations above the drinking water standards are concentrated at depths of $<150 \mathrm{~m}$. Deeper aquifers $(>150 \mathrm{~m})$ in general produce groundwater with arsenic concentrations below the WHO limit $0.01 \mathrm{mg} \mathrm{L}^{-1}$ (Bhattacharya and Jacks 2000); groundwater chemistry of our samples and their collecting sites are given in Table 3 and Fig. 4, respectively. 


\begin{tabular}{|c|c|c|c|c|c|c|c|c|}
\hline 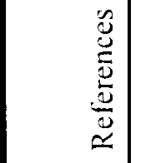 & 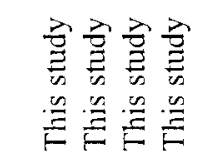 & 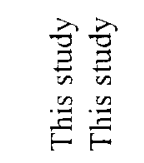 & 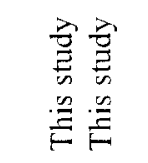 & 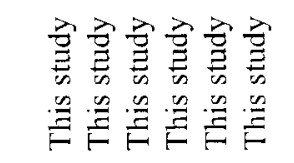 & 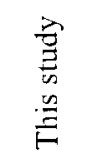 & 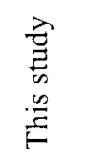 & 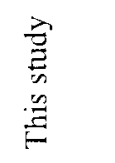 & 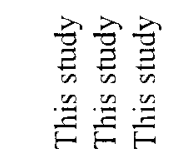 \\
\hline 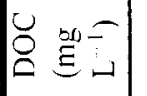 & 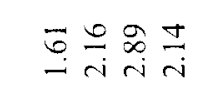 & $\hat{\sigma}_{i}^{\infty} \underset{i}{\infty}$ & $\stackrel{m}{i}$ & 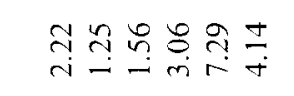 & $\vec{\sigma}$ & $\underset{\dot{g}}{\dot{m}}$ & $\underset{i}{\vec{i}}$ & $\tilde{n} \underset{m}{n} \stackrel{n}{=}$ \\
\hline 要合 & 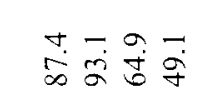 & $\begin{array}{l}0 \\
\dot{\infty}\end{array}$ & $\begin{array}{l}N \mathscr{O} \\
\dot{\alpha}\end{array}$ & 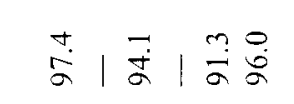 & $\begin{array}{l}\text { के } \\
\text { के }\end{array}$ & $\hat{j}$ & $\ddot{\circ}$ & 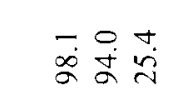 \\
\hline 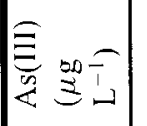 & 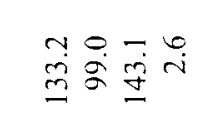 & 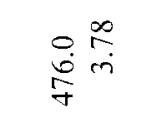 & $\ddot{\varrho}=$ & 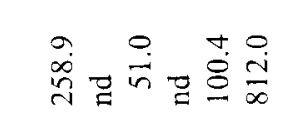 & $\underset{\infty}{\stackrel{\leftrightarrow}{\infty}}$ & $\hat{\dot{B}}$ & $\frac{\Delta}{\Delta}$ & 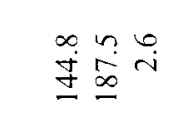 \\
\hline$\frac{5}{2}$ & 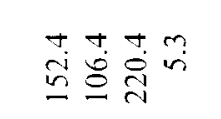 & $\begin{array}{l}0 \stackrel{\infty}{7} \\
\stackrel{\sim}{\sim} \\
\stackrel{\sim}{\sim}\end{array}$ & $\begin{array}{l}n a \\
\equiv a \\
\equiv\end{array}$ & 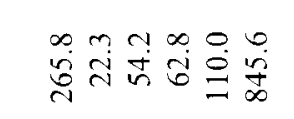 & \begin{tabular}{l}
$m$ \\
\multirow{2}{a}{} \\
$\infty$
\end{tabular} & $\stackrel{a}{2}$ & $\stackrel{m}{i}$ & 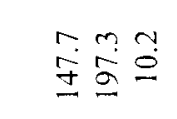 \\
\hline 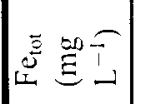 & 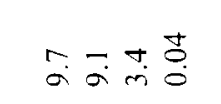 & $\stackrel{m}{m} \stackrel{0}{0}$ & $\stackrel{t i}{a}$ & 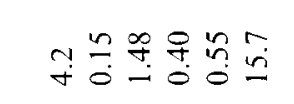 & $\stackrel{+}{ \pm}$ & 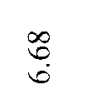 & $\stackrel{\mathcal{F}}{f}$ & 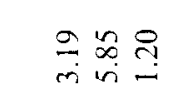 \\
\hline & 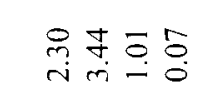 & 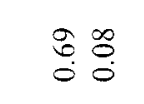 & $\stackrel{\infty}{\sim} \stackrel{\sim}{\dddot{N}}$ & 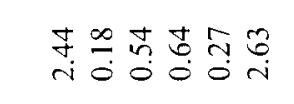 & $\stackrel{?}{i}$ & $\stackrel{\sim}{\pi}$ & $\stackrel{3}{6}$ & 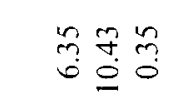 \\
\hline & 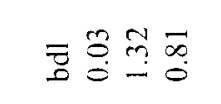 & $\frac{1}{0} \div$ & $\stackrel{\infty}{\stackrel{\infty}{0}} \stackrel{1}{0}$ & 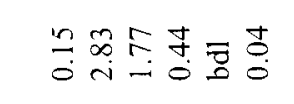 & $\bar{\Xi}$ & s. & $\frac{5}{5}$ & $\bar{\sigma}=\tilde{n}$ \\
\hline 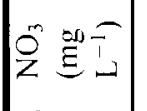 & 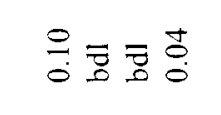 & $\overline{\bar{z}} \overline{\bar{g}}$ & $\stackrel{i}{0} \overline{0}$ & 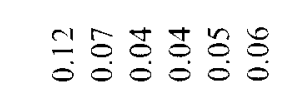 & $\bar{\Xi}$ & $\stackrel{2}{8}$ & $\frac{1}{6}$ & $\stackrel{t}{0} \frac{\infty}{0} \stackrel{\infty}{0}$ \\
\hline 官 & 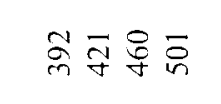 & $g$ & 苦 字 & 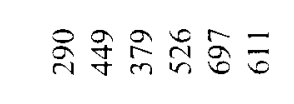 & 点 & g & $\stackrel{n}{g}$ & 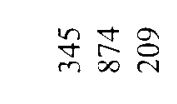 \\
\hline 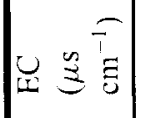 & 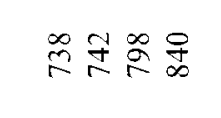 & $\frac{2}{2}:$ & $\frac{1}{\infty} \overline{0}$ & 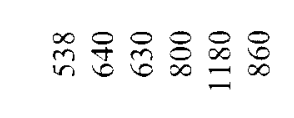 & $\stackrel{\ominus}{\infty}$ & $\S$ & గ్ర & 냉용요 \\
\hline 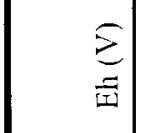 & 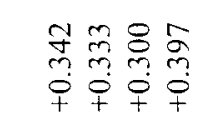 & 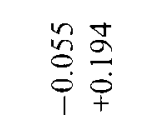 & $\begin{array}{l}\text { 尊尃 } \\
\stackrel{i}{i} \\
i\end{array}$ & 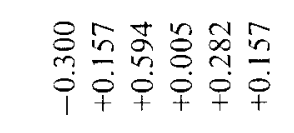 & $\hat{\bar{n}}$ & $\stackrel{\infty}{\frac{\infty}{i}}$ & $\stackrel{0}{0}$ & 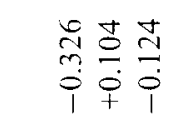 \\
\hline \pm & $m \stackrel{\infty}{b}: 0$ & $\pi$ & ry & 무욤요 & $\stackrel{2}{x}$ & 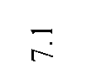 & $\vec{r}$ & 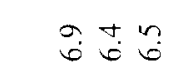 \\
\hline$\vdash \stackrel{0}{0}$ & 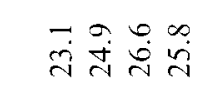 & 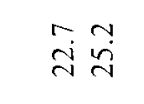 & 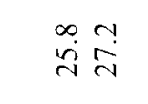 & 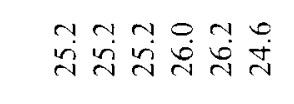 & $\bar{n}$ & $\stackrel{y}{a}$ & $\begin{array}{l}\infty \\
\stackrel{J}{I}\end{array}$ & 究: \\
\hline 咅司 & $\begin{array}{l}0 \\
\dot{0} \\
\dot{i}\end{array}$ & $\underset{\infty}{\infty}=$ & 库 & 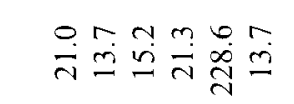 & $\ddot{\sim}$ & $\begin{array}{l}\infty \\
\dot{0}\end{array}$ & $\frac{m}{i}$ & 苛 \\
\hline$\stackrel{0}{2}$ & 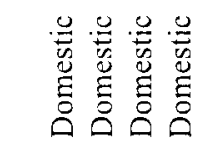 & 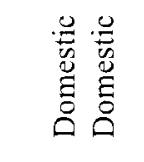 & 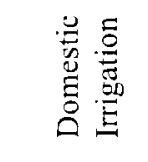 & 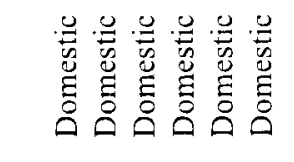 & 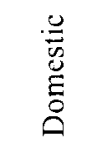 & $\begin{array}{l}\stackrel{\mathscr{Z}}{0} \\
\stackrel{0}{0} \\
\stackrel{0}{0}\end{array}$ & $\begin{array}{l}\stackrel{\mathscr{Z}}{0} \\
\stackrel{0}{0} \\
\stackrel{0}{0}\end{array}$ & 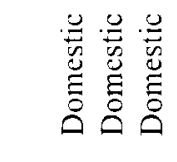 \\
\hline 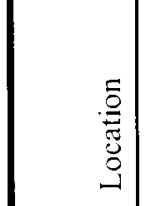 & 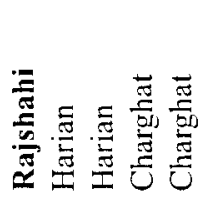 & 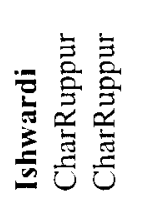 & 童言言 & 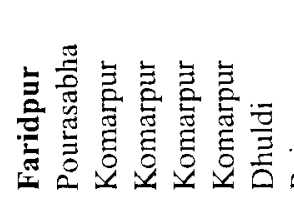 & & . & $=\bar{\Xi}=$ & 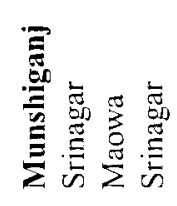 \\
\hline
\end{tabular}




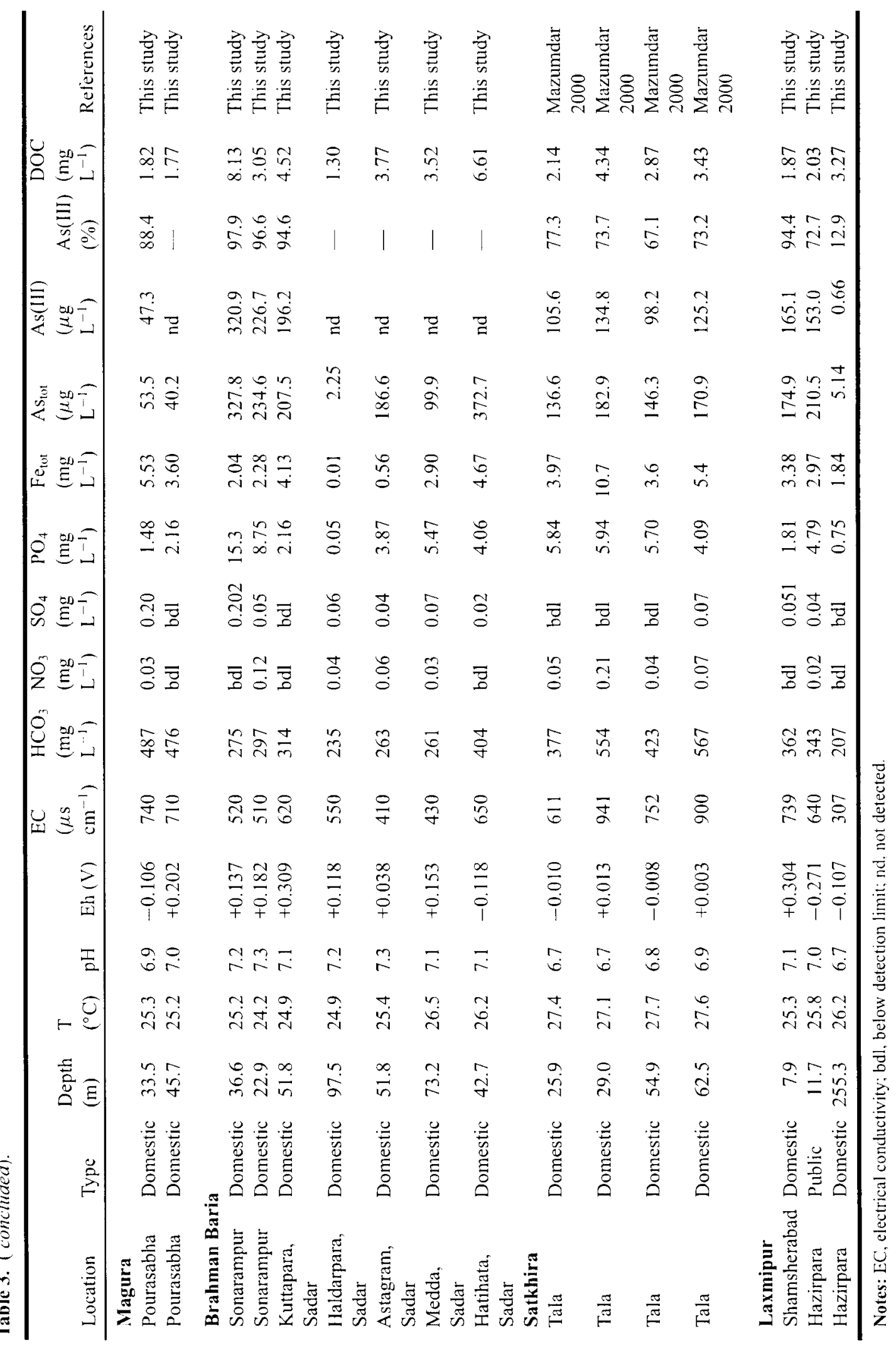


Fig. 4. Groundwater sampling sites (Rajshahi, Iswardi, Faridpur, Meherpur, Munshiganj, Magura, Brahman Baria, Satkhira, Laxmipur) in Bangladesh (this study).

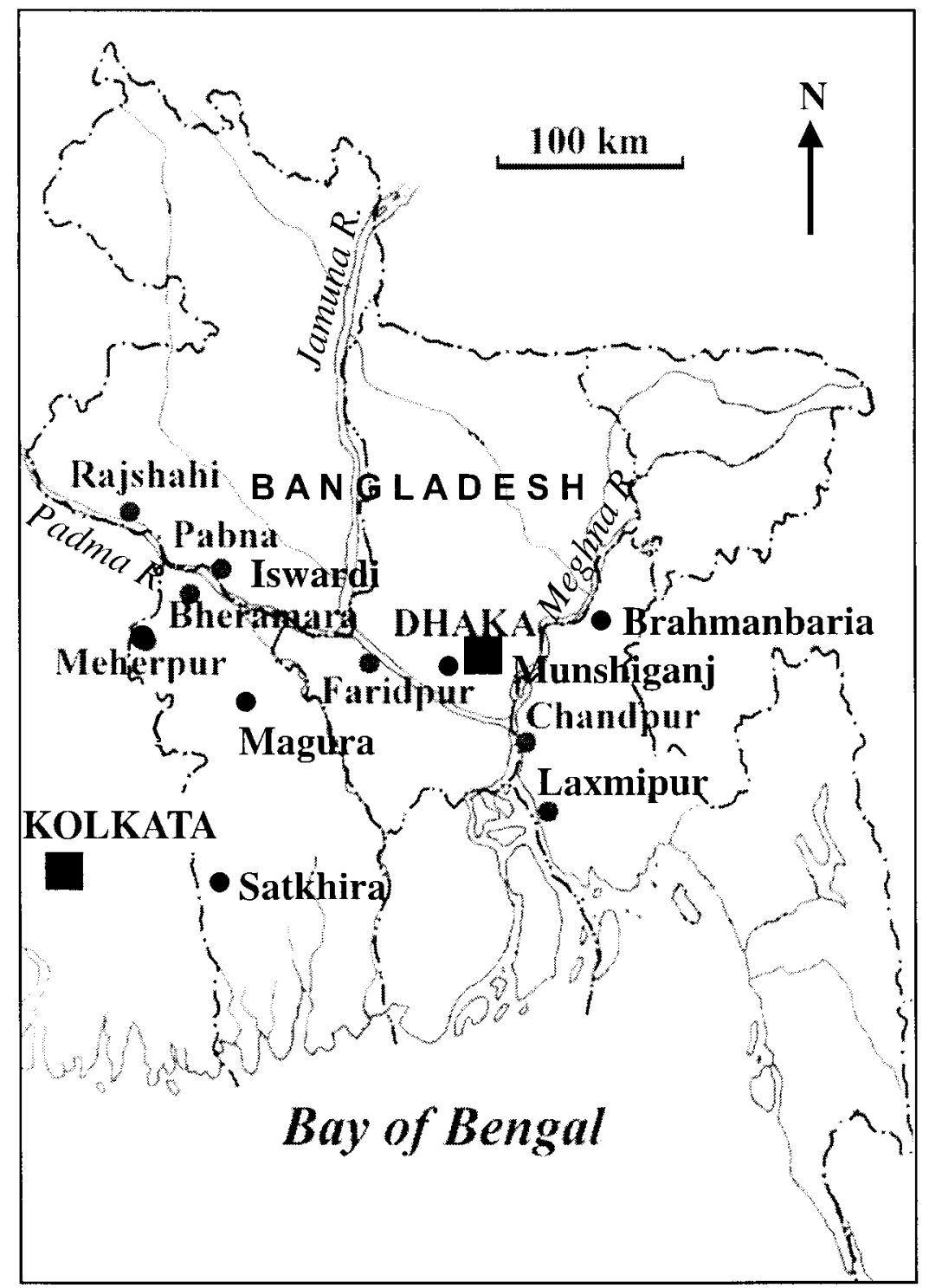

$\mathrm{Fe}_{\text {tot }}$ shows fairly high coefficients of linear regression with $\mathrm{HCO}_{3}\left(r^{2}=0.57\right.$, Fig. $\left.5 a\right)$ as well as with $\mathrm{PO}_{4}\left(r^{2}=0.50 ; p<0.001\right.$, Fig. $\left.5 b\right)$. The linear regression coefficient is comparatively low between $\mathrm{Fe}_{\text {tot }}$ and $\mathrm{As}_{\text {tot }}\left(r^{2}=0.42 ; p=<0.001\right.$, Fig. $\left.5 d\right)$ in the groundwater samples. High $\mathrm{HCO}_{3}$ concentrations are fairly well correlated with the levels of dissolved organic carbon (DOC) (1.15$\left.14.2 \mathrm{mg} \mathrm{L}^{-1}\right)$ in groundwater $\left(p<0.05 ; r^{2}=0.38\right.$, Fig. $\left.5 c\right)$. As(III) and $\mathrm{Fe}_{\text {tot }}$ concentrations in the groundwater show two distinct trends of variations with DOC (Fig. $6 a$ and $b$ ). The source of DOC is however not well known and needs to be investigated further, but the sedimentary organic matter (OM) in the aquifers may be thought to be active source for the DOC in the BDP groundwaters.

In a reducing environment and with low As:Fe ratios, increase in arsenic concentration in groundwater is related to the microbial reduction of arsenate, $\mathrm{As}(\mathrm{V})$, to arsenire, As(III) (Langner and Inskeep 
Fig. 5. Chemical characteristics of groundwater from BDP aquifers in Bangladesh $(n=36)$ showing the relation between (a) $\mathrm{Fe}_{\mathrm{tot}}$ and $\mathrm{HCO}_{3},(b) \mathrm{PO}_{4}$ and $\mathrm{Fe}_{\mathrm{tot}}$, (c) dissolved organic carbon and alkalinity, and (d) $\mathrm{Fe}_{\mathrm{tot}}$ and $\mathrm{As}_{10 \mathrm{t}}$.
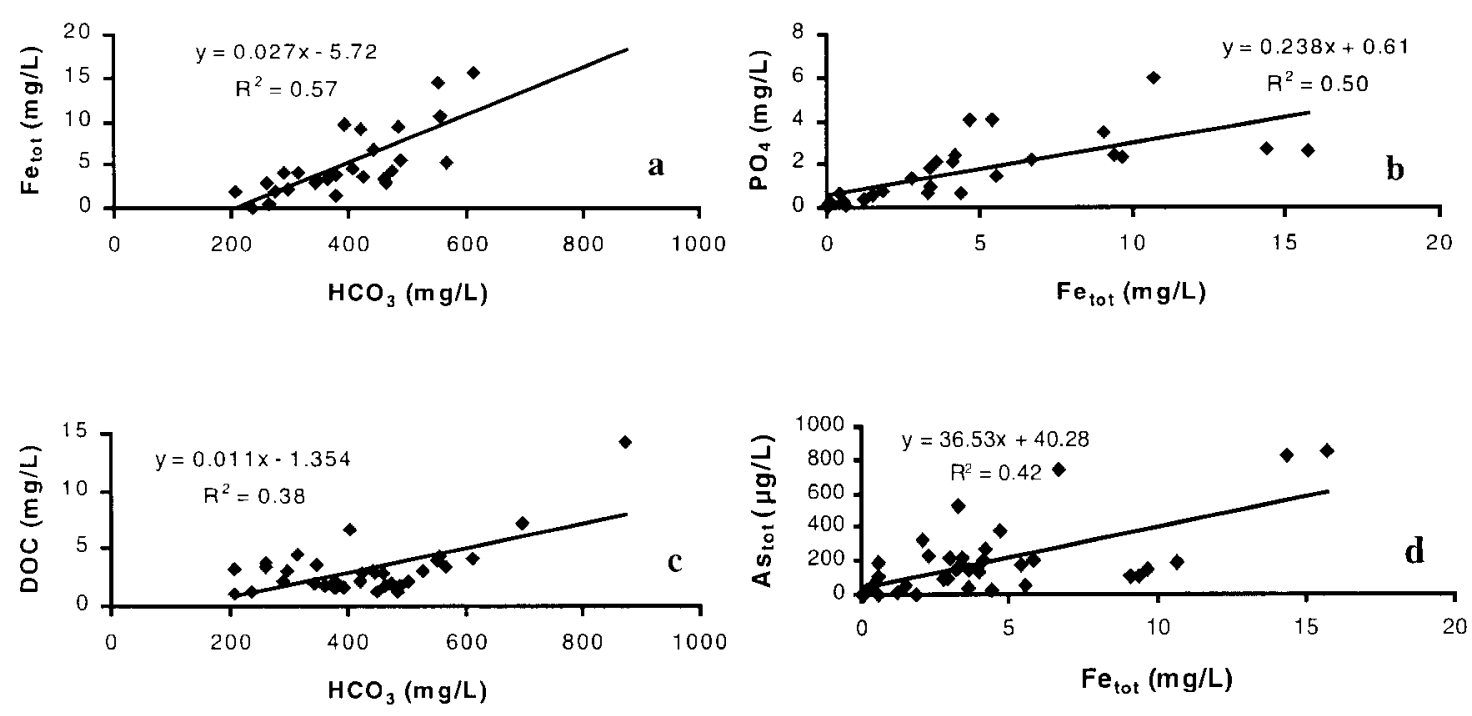

Fig. 6. Sympathetic variation of $\mathrm{Fe}_{\mathrm{tol}}$ and $\mathrm{As}(\mathrm{III})$ with dissolved organic carbon in BDP groundwaters from Bangladesh. The data points with distinct trends suggest that both $\mathrm{As}(\mathrm{III})$ and $\mathrm{Fe}_{\mathrm{tol}}$ are mobilized from the aquifers by DOC consequent to the microbial reduction of the sedimentary organic mattcr.
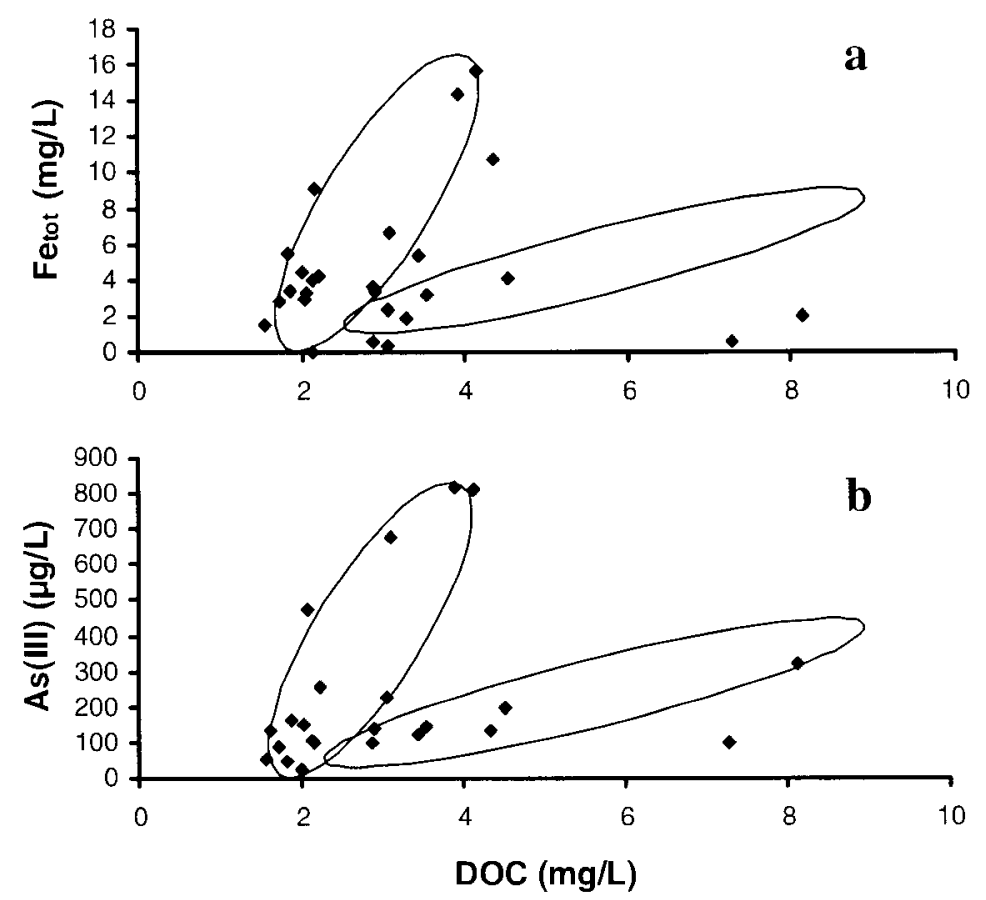

2000), and reductive dissolution of Fe(III) species, which results in the release of arsenic and other trace elements as well as phosphate in groundwater. High DOC levels and dominance of As(III) species in near-neutral and anoxic BDP groundwaters also suggest that reduction of OM by microorganisms may facilitate biomethylation processes, which may result in the conversion of $\mathrm{As}(\mathrm{V})$ to the more soluble As(III) species, thereby affecting the mobility and translocation of arsenic (Routh et al. 2000). 


\subsubsection{Nature and chemistry of the alluvial sediments in the Bengal Delta Plain}

Geochemical analysis of the alluvial aquifers sediments from the BDP have revealed high concentrations of arsenic elevated by factors of 2.5 to $>70$ as compared to the average continental crust. Total arsenic $\left(\mathrm{HNO}_{3}\right.$ extraction, $\left.\mathrm{As}_{\mathrm{NO}_{3}}\right)$ concentrations in the sediments have been estimated to be in the range of 5-14 $\mathrm{mg} \mathrm{kg}^{-1}$ at different locations and depths. Some of the aquifer sediment from Tala (in Satkhira district) revealed high concentrations of arsenic (294 $\mathrm{mg} \mathrm{kg}^{-1}$ ). Considerable variations are also noted for the distribution of $\mathrm{Fe}_{\mathrm{NO}_{3}}\left(57.8-334.9 \mathrm{~g} \mathrm{~kg}^{-1}\right), \mathrm{Al}_{\mathrm{NO}_{3}}\left(36.9-223 \mathrm{~g} \mathrm{~kg}-1\right.$, and $\mathrm{P}_{\mathrm{NO}_{3}}$ $\left(1.5-5.9 \mathrm{~g} \mathrm{~kg}^{-1}\right)$.

Significant positive Spearman rank correlations are noted amongst $\mathrm{As}_{\mathrm{NO}_{3}}$ and $\mathrm{Fe}_{\mathrm{NO}_{3}}(p<0.001)$, $\mathrm{Al}_{\mathrm{NO}_{3}}(p<0.05), \mathrm{MnNO}_{3}(p<0.001)$, and $\mathrm{P}_{\mathrm{NO}_{3}}(p<0.05)$ in the aquifer sediments (Fig. $\left.7 a-d\right)$. The dominance of Fe-oxyhydroxides in the sediments is revealed by higher quantities of oxalate extractable iron $\left(\mathrm{Fe}_{\mathrm{ox}}=4.2-174 \mathrm{~g} \mathrm{~kg}^{-1}\right)$ than aluminum $\left(\mathrm{Al}_{\mathrm{ox}}=0.6-43.7 \mathrm{~g} \mathrm{~kg}^{-1}\right)$ or manganese $\left(\mathrm{Mn}_{\mathrm{ox}}=0.1-\right.$ $\left.4.5 \mathrm{~g} \mathrm{~kg}^{-1}\right)$. The amount of oxalate extraction arsenic $\left(A \mathrm{~s}_{\mathrm{Ox}}\right)$ varies between 1.7 and $86.4 \mathrm{mg} \mathrm{kg}^{-1}$. Strong correlation (Fig. $8 a$ and $b$ ) is also noted amongst $\mathrm{Fe}_{\mathrm{NO}_{3}}$ and $\mathrm{Fe}_{\mathrm{Ox}}(p<0.001)$ and $\mathrm{As}_{\mathrm{NO}_{3}}$ and $\mathrm{As}_{\mathrm{OX}}(p<0.001)$. Among the oxalate extractable fractions, high correlation (Fig. $\left.9 a-d\right)$ exist between $\mathrm{As}_{\mathrm{ox}}$ and $\mathrm{Fe}_{\mathrm{ox}}(p<0.01), \mathrm{Al}_{\mathrm{ox}}(p<0.05), \mathrm{Mn}_{\mathrm{ox}}(p<0.001)$, and $\mathrm{P}_{\mathrm{ox}}(p<0.05)$. Correlation between oxalate extractable arsenic and the secondary amorphous Fe-, Al- and Mn-oxyhydroxides in the sediments, however, implies that they act as the principal adsorbent for arsenic in the BDP aquifers sediments (Bhattacharya et al. 2001).

\subsubsection{Mechanisms of arsenic mobilization}

Though the causes of widespread occurrences of arsenic in groundwater of the BDP are a matter of debate, the basic geochemical processes that might be responsible for the problem are well established (von Brömssen 1999; Bhattacharya et al. 1999a, 1999b, 2001; Bhattacharya and Mukherjee 2000; Mazumdar 2000; Nickson et al. 2000).

Pyrite oxidation is cited as a plausible hypothesis for the widespread arsenic contamination of the BDP groundwater (Das et al. 1996; Roy Chowdhury et al. 1999 and many others). Pyrite is oxidized in aquifer sediments where groundwater is oxygenated according to the reaction

[1] $\mathrm{FeS}_{2}+\frac{15}{4} \mathrm{O}_{2}+\frac{7}{2} \mathrm{H}_{2} \mathrm{O}=\mathrm{Fe}(\mathrm{OH})_{3}+2 \mathrm{SO}_{4}{ }^{2-}+4 \mathrm{H}^{+}$

while the oxidation of arsenopyrite follows the reaction

$$
\text { [2] } \mathrm{FeAsS}+13 \mathrm{Fe}^{3+}+8 \mathrm{H}_{2} \mathrm{O}=14 \mathrm{Fe}^{2+}+\mathrm{SO}_{4}{ }^{2-}+13 \mathrm{H}^{+}+\mathrm{H}_{3} \mathrm{AsO}_{4}(\mathrm{aq})
$$

Both these reactions produce water with high concentrations of $\mathrm{Fe}^{2+}$ and $\mathrm{SO}_{4}{ }^{2-}$ accompanied by a decrease in $\mathrm{pH}$. Validity of this hypothesis is under sharp criticism because the groundwaters in this region are (i) anoxic, with no or negligible dissolved oxygen; (ii) at near neutral $\mathrm{pH}$; (iii) strongly alkaline; (iv) characterized by low sulfate concentrations with no relationship with arsenic; and (v) characterized by virtual absence of nitrate (Bhattacharya et al. 1999b; BGS/MML 1999a).

Mobilization of arsenic from the alluvial aquifers is primarily due to the mechanism of desorption of arsenic oxyanions from the surface of Fe-oxyhydroxides as well as reductive dissolution of the Fe-oxyhydroxides in the sediments (Bhattacharya et al. 1996, 1997; Nickson et al. 1998; BGS/MML $1999 a$ ). The present study suggests that the bulk of the arsenic in the sediments is quantitatively related to the amounts of the amorphous Fe-, Al-, and Mn-oxyhydroxides in the sediments. These surface reactive compounds are characterized by a positive charge and therefore act as a strong adsorbent for the arsenic oxyanions (Pierce and Moore 1982). Increased $\mathrm{pH}$ of groundwater releases arsenic oxyanions by desorption, and the inflow of DOC-charged, anoxic water from the cultivated wetlands (rice fields) facilitates the dissolution of Fe-oxyhydroxides under the prevalent reducing conditions. 

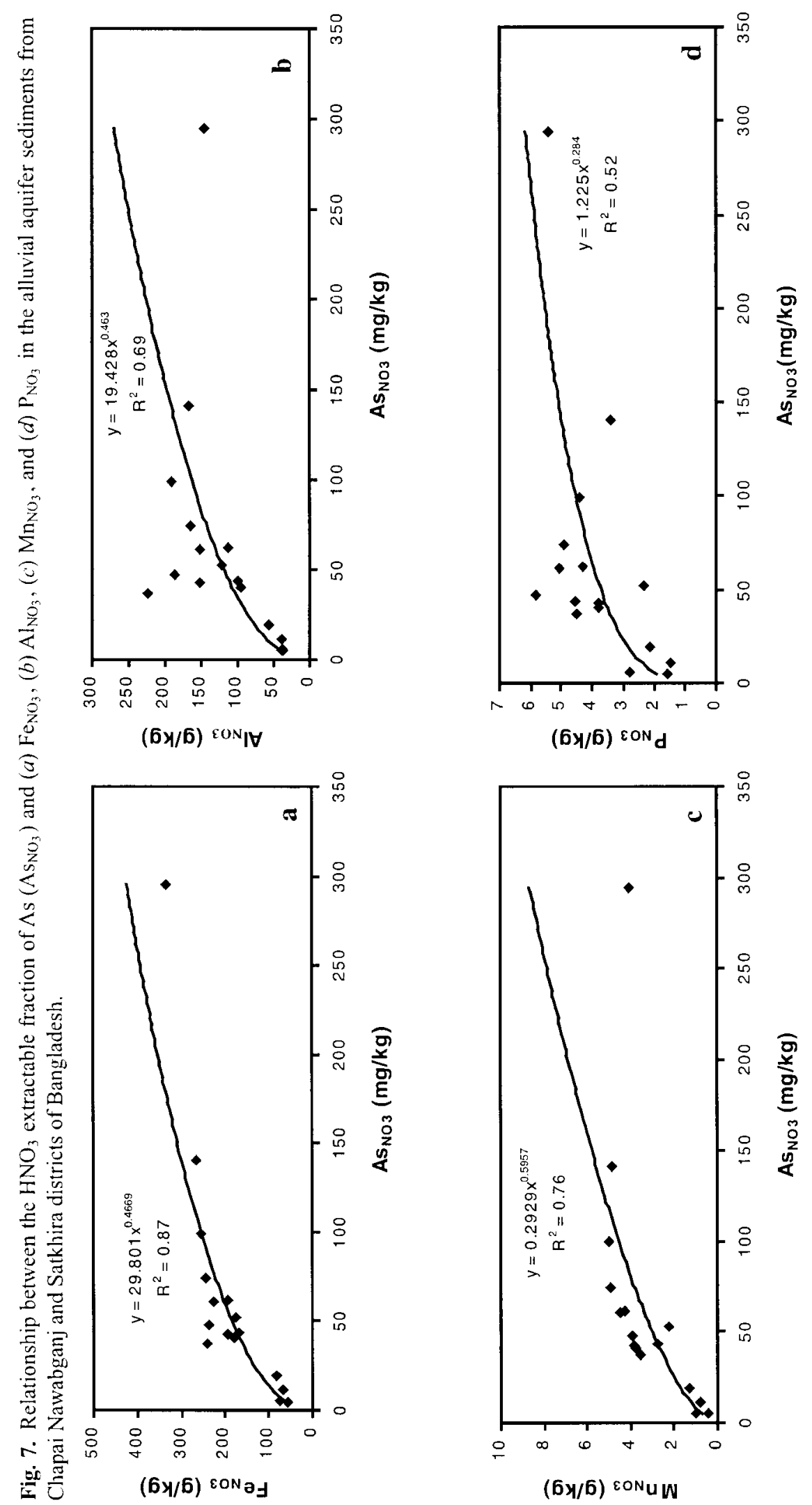

$(6 y / 6)^{\varepsilon O N} d$

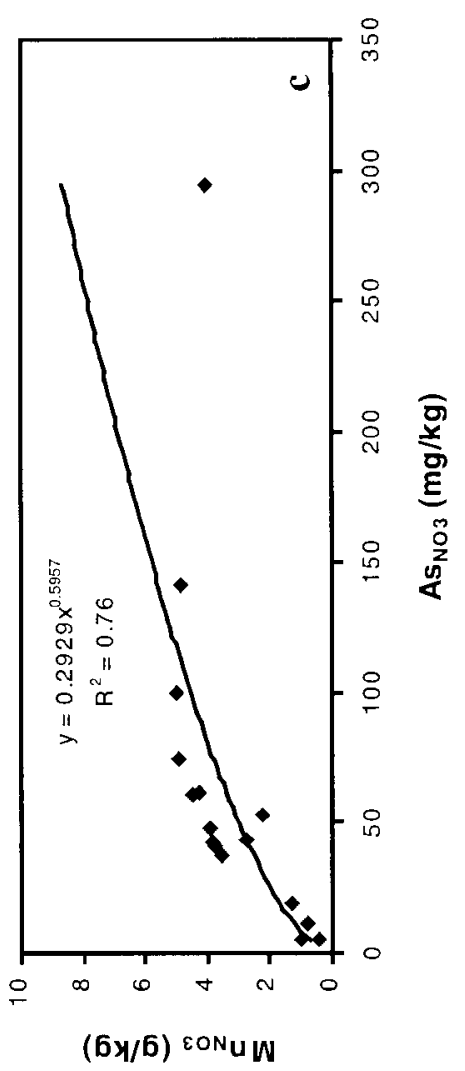

$\$ 2001$ NRC Canada 
Fig. 8. Relation between the $\mathrm{HNO}_{3}$ extractable and oxlate extractable fraction of $\mathrm{Fe}$ and $\mathrm{As}$ in the aquifer sediments.
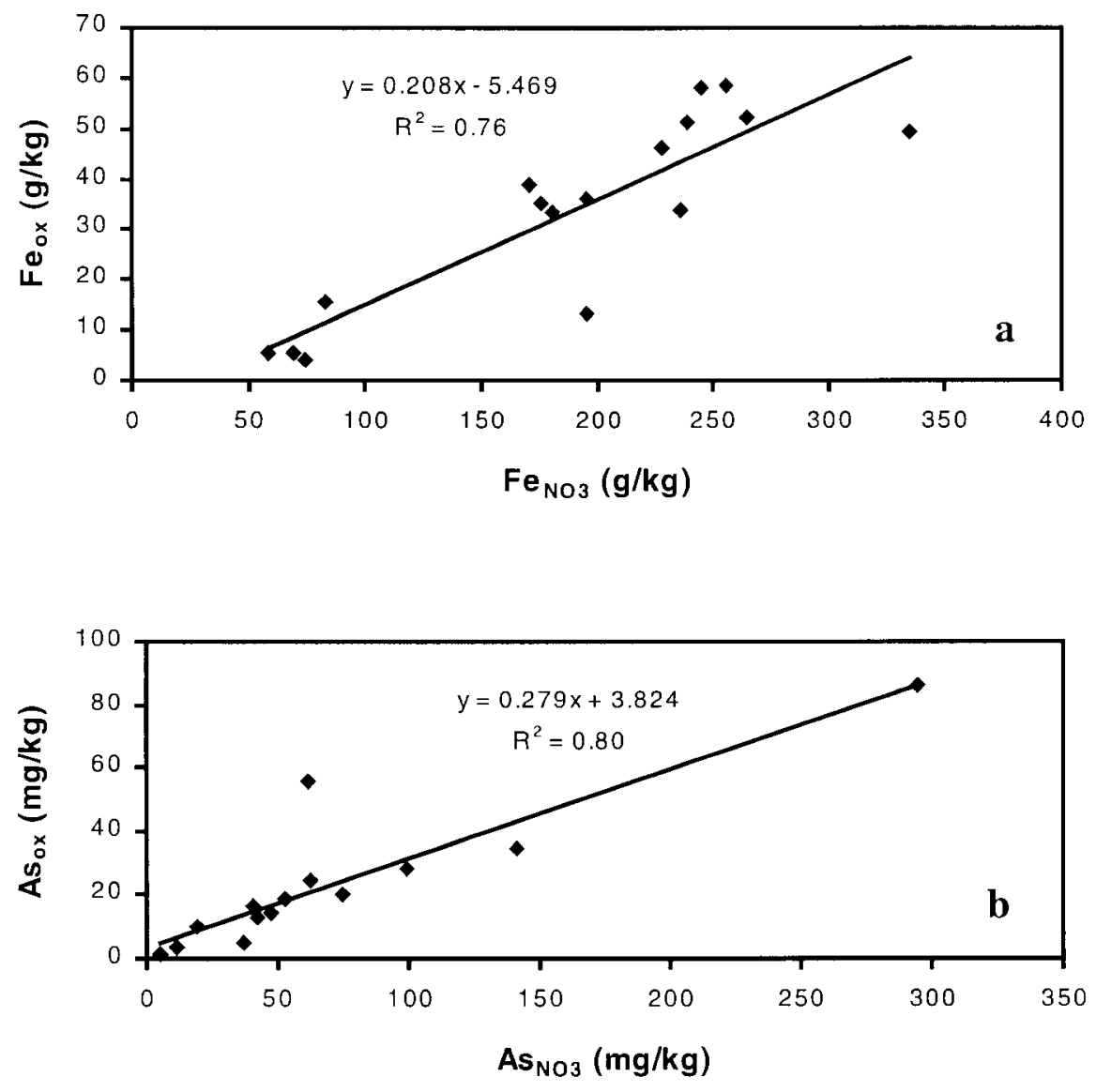

Consumption of the dissolved oxygen and other oxidants (such as nitrate) mediate the oxidation of the sedimentary $\mathrm{OM}$ in the aquifers, thereby increasing the groundwater alkalinity (Bhattacharya et al. 1997, 2001). High alkaline groundwater in the BDP aquifers may thus be produced by (i) oxidation of organic matter in the presence of oxygen, expressed by the reaction

$$
\mathrm{CH}_{2} \mathrm{O}+\mathrm{O}_{2}=\mathrm{CO}_{2}+\mathrm{H}_{2} \mathrm{O}
$$

and

(ii) bacterially mediated reduction of nitrate by organic matter, following the reaction

$$
\text { [4] } 5 \mathrm{CH}_{2} \mathrm{O}+\mathrm{HNO}_{3}^{-}=2 \mathrm{~N}_{2}+4 \mathrm{HCO}_{3}^{-}+\mathrm{CO}_{2}+3 \mathrm{H}_{2} \mathrm{O}
$$

Bacterial reduction plays an important role in these aquifers because both nitrate and sulfate concentrations are low. High $\mathrm{NH}_{4}{ }^{+}$concentrations in this groundwaters (Mazumdar 2000; Bhattacharya and Jacks 2000) also tend to suggest that bacterially mediated nitrate reduction processes are taking place in these aquifers (for example, Zehnder 1988; Smith et al. 1991). Studies by Larsson and Leiss (1997) and Bhattacharya et al. (1997) also pointed out that sedimentary arsenic can be mobilized by microbial degradation in the presence of organic substrates in reducing aquifers. Our studies reveal well-defined correlation between the concentrations of bicarbonate with $\mathrm{Fc}_{\text {tot }}$ as well as the DOC. Sedimentary and dissolved $\mathrm{OM}$ serve as electron donors that control the key redox reactions (e.g., $\mathrm{NO}_{3}{ }^{-}$and $\mathrm{SO}_{4}{ }^{2-}$ reduction, dissolution of $\left.\mathrm{Fe}(\mathrm{OH})_{3}\right)$ in the aquifers. The correlation amongst $\mathrm{Fe}_{\text {tot }}$ and $\mathrm{As}_{\text {tot }}$, as well as 

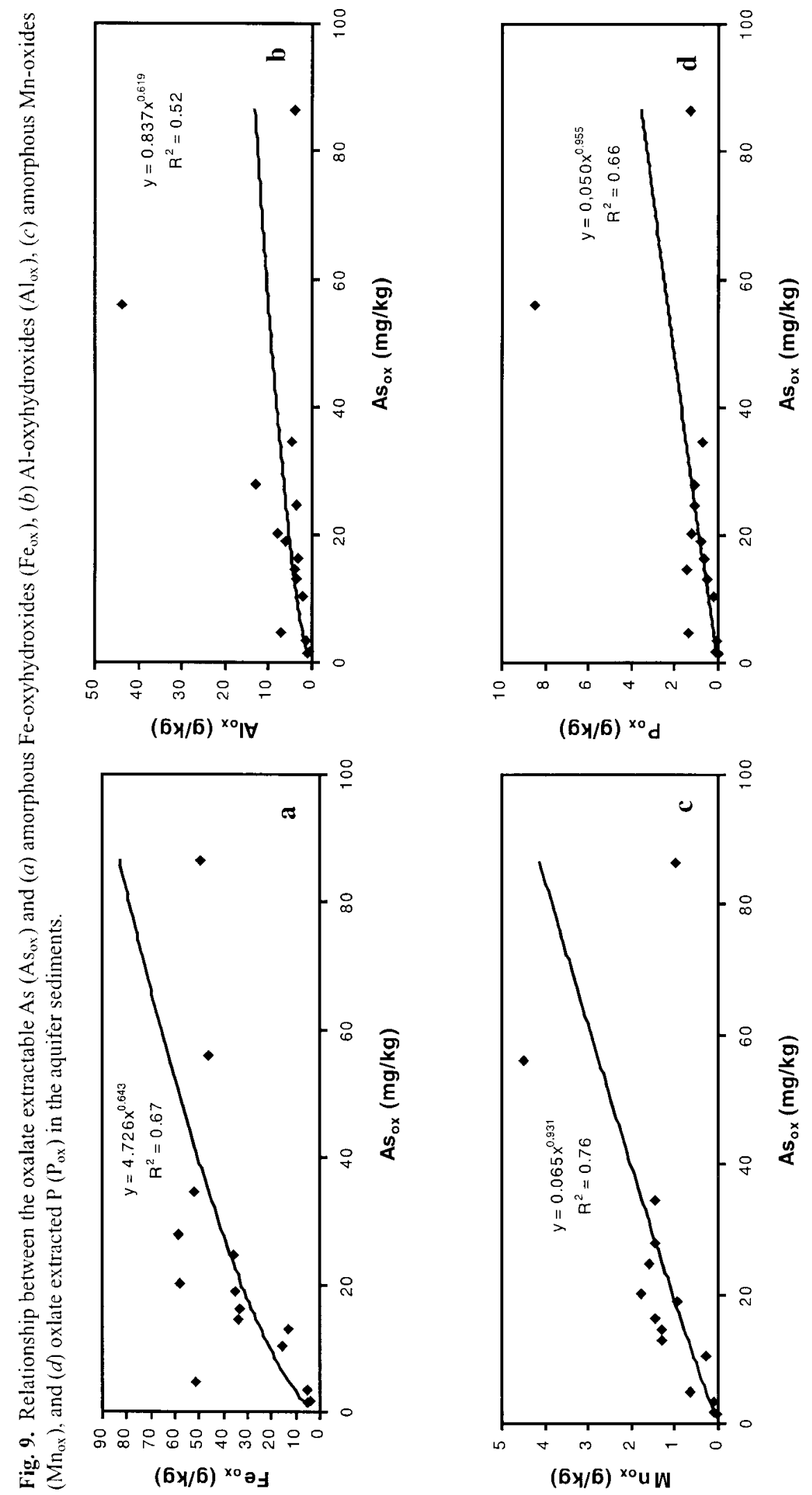

C2001 NRC Canada 
Table 4. Estimated daily intake of arsenic in the affected areas of Bangladesh.

\begin{tabular}{|c|c|}
\hline Population at risk of the affected districts & 75 million \\
\hline Drinking water habits including rice water $\left(\mathrm{L} \mathrm{d}^{-1}\right)^{b}$ & 5 \\
\hline As concentration $\left(\mu \mathrm{g} \mathrm{L}^{-1}\right)$ & $>50-1000$ \\
\hline As intake per person per day $\left(\mu \mathrm{g} \mathrm{d}^{-1}\right.$ person $\left.{ }^{-1}\right)$ & $>250-5000$ \\
\hline Intake for affected population (ca. 75 million) $\left(\mathrm{t} \mathrm{a}^{-1}\right)$ & $5.48-11$ \\
\hline
\end{tabular}

$\mathrm{PO}_{4}$ in the groundwater, suggest that both, as well as $\mathrm{PO}_{4}{ }^{3-}$, are released to the groundwater following reductive dissolution of $\mathrm{Fe}(\mathrm{OH})_{3}$. However, the correlation among these parameters can be masked because of the precipitation of siderite $\left(\mathrm{FeCO}_{3}\right)$ and to some extent vianite $\left(\mathrm{Fe}\left(\mathrm{PO}_{4}\right)_{2} \cdot 8 \mathrm{H}_{2} \mathrm{O}\right)$, which act as the sink for $\mathrm{Fe}^{2+}$ in the reducing aquifers (Sracek et al. 2000). Arsenic-rich pyrites (framboidal pyrite) on the other hand are formed diagenetically in the clayey sediments in the sulfate reducing zone. These secondary sulfides, however, act as a sink for arsenic and remain stable under reducing conditions (Ahmed 1999; Bhattacharya et al. 1999b). All this evidence suggests that arsenic mobilization from the alluvial aquifers in the BDP occurs predominantly under the reducing environment and the mechanism is controlled by the dissolution of Fe-, $\mathrm{Al}$-, and (or) Mn-oxyhydroxides due to the biogeochemical interactions in the aquifers.

\section{The role of arsenic in biology, health, and society of Bangladesh}

\subsection{Drinking water}

For the last 2000 years, arsenic has been used as a medicine while at the same time being known to be a poison. In the last decades, high levels of arsenic concentration in groundwater from natural and industrial sources have created environmental pressures in different regions of the globe. In many areas, groundwater is used for drinking purpose, as it is safe. Generally, drinking water and the food chain are the main pathways by which one can be exposed to the poisonous effects of arsenic. It has already been discussed how the arsenic level in groundwater in Bangladesh varies from one region to another because of geological and geomorphological nature of the areas as well as the fact that the aquifers are shallow (see Table 3 and Fig. 1). The information indicates how groundwater arsenic concentration varies with shallow aquifers $(<150 \mathrm{~m})$. Even old and new types of wells generate different results, which cannot be explained. However, different studies indicate that in the affected areas, groundwater arsenic concentration varies between $>50$ and $1000 \mu \mathrm{g} \mathrm{L}^{-1}$ (maximum permissible limit in Bangladesh: $50 \mu \mathrm{g} \mathrm{L}^{-1}$ ). Occasionally, very high concentrations of arsenic in shallow tubewells in Pabna (14 $\mathrm{mg} \mathrm{As}^{-1}$ ) and in Kushtia (9 $\mathrm{mg} \mathrm{As} \mathrm{L}^{-1}$ ) were reported (The New Nation 1996; DCH 1997). It is possible to estimate the daily intake of arsenic from drinking water in the affected areas and this is shown in Table 4. Daily inorganic arsenic intake for the adult population in the affected areas varies between $>250$ and $5000 \mu \mathrm{g} \mathrm{day}^{-1}$ as compared to $5 \mu \mathrm{g}$ day $^{-1}$ in the United States (US EPA 1982). This high intake originates not only from drinking water, but also from drinking rice-water and water used for cooking.

\subsection{Food chain}

Use of high arsenic content groundwater for irrigation has resulted in the accumulation of arsenic in crops and plants. Based on the studies carried out so far, it is significant to note that high concentrations of arsenic in vegetables and rice in affected areas, such as Chandipur village in Laximpur (Table 5), indicate that dietary habits are also responsible for arsenic problems for the people of Bangladesh (Huq et al. 2001). The arsenic concentration values of vegetables grown in Bangladesh should not be 
Table 5. Arsenic concentration $\left(\mu \mathrm{g} \mathrm{g}^{-1}\right)$ in vegetables in an affected area in Bangladesh (Huq et al. 2001). Figures rounded.

\begin{tabular}{llll}
\hline & \multicolumn{3}{l}{ Arsenic concentration $\left(\mu \mathrm{g} \mathrm{g}^{-1}\right)$} \\
\cline { 2 - 4 } Samples & Min & Max & Average \\
\hline Rice (Oryza sativa) & 0.44 & 0.5 & 0.47 \\
Kochu, leaf (Colocasia antiquorum) & 0.11 & 0.11 & 0.11 \\
Kochu, stem (Colocasia antiquorum) & 0.74 & 0.92 & 0.83 \\
Kochu, creeper (Colocasia antiquorum) & 0.21 & 0.23 & 0.22 \\
Gourd, leaf (Lagenoria siceraria) & 1.88 & 2.01 & 1.94 \\
Brinjal (Solanum melongena) & 0.18 & 0.20 & 0.19 \\
Sweet potato, leaf (Ipomea batatus) & 0.38 & 0.41 & 0.40 \\
Pui shak (Basilia alba) & 0.30 & 0.33 & 0.31 \\
Kalmi shak (Ipomea aquatica) & 0.29 & 0.35 & 0.32 \\
Papaya (Carica papaya) & 0.19 & 0.26 & 0.22 \\
Red pumpkin (Cucurbita maxima) & 0.20 & 0.27 & 0.24 \\
\hline
\end{tabular}

compared to that of vegetables grown in Europe, as the species grown in Bangladesh are completely different to those grown in Europe.

Fish constitutes an important part of the diet in Bangladesh. Concentration of arsenic in water is not always responsible for the arsenic level in fish species. Most important is how a metal is transferred tropically through the food webs and, for example, whether it is biomagnifiable or biodiminishable. Fish species have different food habits. Planktivorous species (e.g., alewives and killifish) may contain considerably more arsenic than ominivorous species (bluegill and yellow perch) or piscivorous species (large mouth bass) (Fig. 10) (Chen and Folt 2000). Although there are no values for the arsenic concentrations in fish in Bangladesh, it is important to note that much of the arsenic present in fish and shellfish is in either the fat-soluble or water-soluble organoarsenic form that is essentially non-toxic (Lunde 1973). A recent study in the Netherlands suggests that in seafood $0.1-41 \%$ of the arsenic is present as inorganic arsenic (Vaessen and van Ooik 1989; ATSDR 1993). Canadian studies have indicated that the arsenic in sea fish was 74-91\% organic arsenic, whereas in lake fish this was 71-85\% (Lawrence et al. 1986). In Canadian ocean fish and lake fish, total arsenic was reported at 4.2 and $0.08 \mathrm{mg} \mathrm{kg}^{-1}$, respectively (Lawrence ct al. 1986), whereas for Finland the total arsenic concentration was between 0.61 and $0.12 \mathrm{mg} \mathrm{kg}^{-1}$ (Liukkonen-Lilja 1993). Hence, we believe that also in Bangladesh total arsenic concentration in river or ocean fish will vary from one species to another. Total arsenic (inorganic and organic) intake derived from foods for a number countries are given in Table 6. In Japan, higher values have been cited; these are due to presence of a higher percentage of organic arsenic in fish species.

\subsection{Impact of high arsenic ingestion}

The toxic properties of arsenic have been known for centuries. The symptoms of acute intoxication of arsenic have been reported in many countries, including Argentina, Bolivia, Chile, Taiwan, India, Bangladesh, and others (Borgoño et al. 1977; Guha Mazumder et al. 1988; 1992). According to $\mathrm{FAO} / \mathrm{WHO}(1998)$, the daily acceptable maximum range of arsenic intake for a healthy $70 \mathrm{~kg}$ person via air, water, and food is as follows: air, $0.8-30 \mathrm{ng} \mathrm{m}^{-3}$; water, $10-50 \mu \mathrm{g} \mathrm{L}^{-1}$; and food, $0.8-120 \mu \mathrm{g} \mathrm{kg}^{-1}$. An interesting study has been done by Tondel et al. (1999) regarding arsenic associated skin lesions from four villages in the districts Faridpur, Jessore, Narayanganj, and Nawabganj in Bangladesh. Their study indicated high prevalence rate of hyperpigmentation for males $(22.7 / 100)$ and females $(11.5 / 100)$ who drink tubewell water containing arsenic of concentrations $>800 \mu \mathrm{g} \mathrm{L}^{-1}$. In these areas, maximum arsenic concentration in drinking water was $3400 \mu \mathrm{g} \mathrm{L}^{-1}$. Analyses of arsenic in urine $\left(0.05-9.42 \mathrm{mg} \mathrm{L}^{-1}\right)$, hair $\left(1.1-19.84 \mathrm{mg} \mathrm{kg}^{-1}\right)$, fingernails $\left(1.3-33.98 \mathrm{mg} \mathrm{kg}^{-1}\right)$, and skin 
Fig. 10. Variation of arsenic concentration in planktivores (AWF, alewife; KLF, Killfish), ominovores (BLCR, Black crappie; BGS, Blucgill sunfish; YP Yellow pearch), and piscivores (LMB, Largemouth bass) fish specics. Fish species are from lakes in New Hampshire, U.S.A. (modified from Chen and Folt 2000).

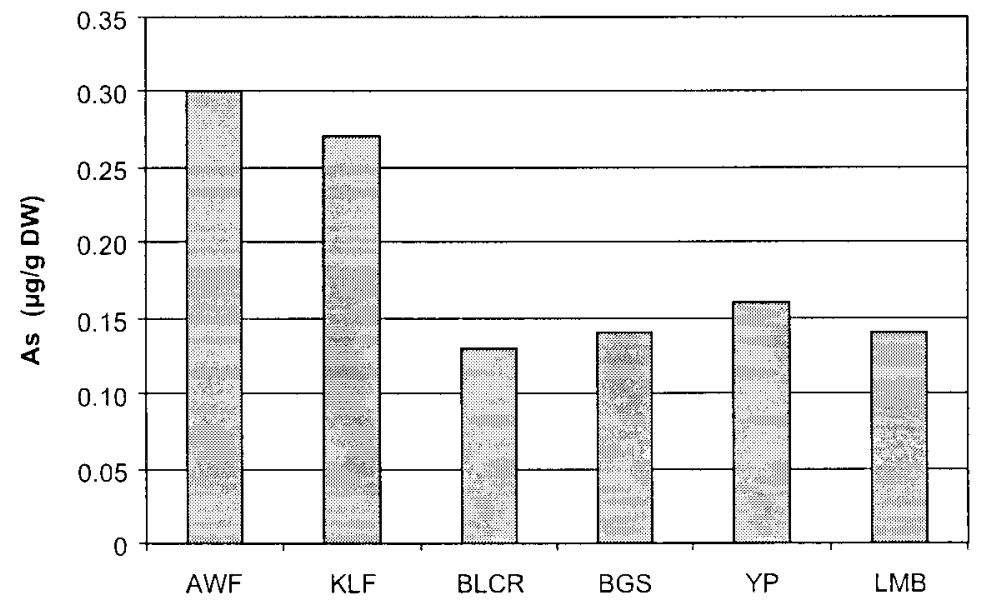

Table 6. Total arsenic (inorganic + organic) intake from foods in selected countries. Source: Liukkonen-Lilja (1993).

\begin{tabular}{lll}
\hline Country & $\begin{array}{l}\text { Arsenic intake } \\
\left(\mu \mathrm{g} \mathrm{As} \mathrm{d}^{-1}\right)\end{array}$ & Year \\
\hline Switzerland & 30 & 1987 \\
Holland & 38 & 1989 \\
Canada & 49 & 1993 \\
Finland & 58 & 1980 \\
Germany (West) & 67 & 1983 \\
England & 89 & 1982 \\
Denmark & 118 & 1990 \\
Japan & 197 & 1990 \\
PTWI" & $130^{b}$ & \\
\hline "PTWI, Provisional Tolerable Weekly Intake. \\
"Inorganic As intake per day is based on the \\
weight of a person of 60 kg.
\end{tabular}

scale (0.6-53.39 $\left.\mathrm{mg} \mathrm{kg}^{-1}\right)$ indicate severe contamination among the affected population in Bangladesh (Chowdhury et al.1999; Karim 2000). The accepted safe limits include urine, $0.005-0.04 \mathrm{mg} \mathrm{d}^{-1}$; hair, $0.08-0.25 \mathrm{mg} \mathrm{kg}^{-1}$; and fingernails, 0.43-1.08 $\mathrm{mg} \mathrm{kg}^{-1}$ (Arnold et al. 1990; Samanta et al. 1999; Karim 2000). Dose response relationships between inorganic arsenic exposure from tubewell water and risk of hypertension, diabetes mellitus, and keratosis were established in Bangladesh and many other countries, including Taiwan and Sweden (Lai et al. 1994; Rahman et al. 1996, 1998, 1999). At least 7000 people are suffering from arsenicosis and 30-70 million people are thought to be exposed to toxicity by arsenic (DCH 1998; Dainichi Consultant, Inc. 1999). The toxic effects of inorganic arsenic are skin lesions, hyperkeratosis, skin cancer, liver disease, and hyperpigmentation (WHO 1981; Morton and Dunnette 1994). High concentration of arsenic $\left(1,860 \mu \mathrm{g} \mathrm{L}^{-1}\right)$ was also reported at the Zhi Ji Liang village of Inner Mongolia, China. In three villages of that area more than 168 patients were diagnosed as suffering from chronic arsenic poisoning (e.g., hyperkeratosis, hyperpigmentation, and skin lesions) (Luo et al. 1997). Toxicity is determined on the basis of ingestion of arsenic compounds and their excretion from the body. It is expected that $40-60 \%$ of the arsenic is retained by the human body (Farmer and Johnson 
1990). The half life of arsenic in humans is cited at 28 to 49 days (Pomroy et al. 1980; Buchet et al. 1980).

\subsection{Social implications}

Arsenic, king of poisons, has brought deep social problems to the communities of Bangladesh. The country is highly populated, which has forced the nation to intense use of land, forest, fisheries, and water resources. This has created severe environmental pressure on cultivation, soil fertility, excess extraction of water for irrigation, commercial fish farming, and use of agricultural chemicals. It is obvious that national economics are based on the commodities and services derived from ecosystems. But little attention has been paid to the ecosystem. Pressure is mounting quickly because of the disturbed sociocconomic conditions of the country. Some people mistake skin disorders resulting from arsenocosis for leprosy. Married women affected by arsenic are sent back to their parents with their children. Affected children are prevented from attending school, and many young men are deprived of jobs when employers find black spots on their body and hands. Affected young unmarried women and men are advised to stay unmarried. They are not allowed even to go to their neighbors to fetch water. Social problems in the affected areas know no bounds (Biswas et al.1998; Samanta et al. 1999). It is observed that poor people are most badly affected by arsenic concentration in groundwater. But still much needs to be understood regarding the impact of arsenic poisoning. Some family members or communities are affected from arsenic poisoning, whereas members in the same family or community who are subject to the same contamination are not. Campaigns are currently ongoing to make people understand that those sick from arsenic are not a threat to others, but deserve attention and care. UNICEF has launched the Facts for Life (FfL) program to promote "awareness about the need for sensitivity to emerging social issues, such as children and women being ostracized when they show signs of being affected by arsenic" (Anon by Bangladesh-UNICEF).

\section{Arsenic removal}

Arsenic removal technologies are available, but cost effective methods are necessary for the people of Bangladesh. As mentioned above, arsenic is present in the aquatic environment as reduced As(III) and oxidized As(V). As the chemical forms of arsenic are different, it is necessary to estimate the speciation of arsenic before adopting any removal technology. In Bangladesh, groundwater contains 43-98\% inorganic arsenic as As(III) (Rasul et al. 1999), which is more toxic than As(V) (Korte and Fernando 1991). It has been reported that it is not possible to remove arsenic(III) from the water in question, but it must first be oxidized to arsenic(V) (Gottschalk et al. 1992). Figure 11 summarizes the available arsenic removal methods. It is worth mentioning that UNICEF and DPHE (Department of Public Health Engineering in Bangladesh) have financed a project at the Bangladesh University of Engineering and Technology to evaluate the use of activated alumina for arsenic removal. In addition, groundwater arsenic research is ongoing in the Division of Land and Water Resources at the Royal Institute of Technology, Stockholm, Sweden. In this institution, low-cost techniques for removal of arsenic from groundwater have been identified. These include (i) auto-attenuation, (ii) use of geological materials as natural adsorbent for arsenic, such as laterite or Fe-rich oxisols, and (iii) reinfiltration of groundwater to the aquifers following aeration. Studies by Larsson et al. (1999) indicated that laterite (consisting mainly of hydrous oxides of $\mathrm{Fe}$ and $\mathrm{Al}$ and minor amounts of $\mathrm{Mn}$ and $\mathrm{Ti}$ ) adsorbed 50-90\% of arsenic from contaminated groundwater (Fig. 12). Among the above-mentioned techniques, the most encouraging method to purify arsenic-laden groundwater is auto-attenuation. Details of these processes may be found elsewhere (Larsson et al. 1999; Bhattacharya et al. 2000).

The United States Environmental Protection Agency (USEPA) has recently identified three promising methods for the removal of arsenic from groundwater: $(i)$ ion exchange with brine recycles, $(i i)$ attenuation method, and (iii) coagulation/filtration in the presence of iron. 
Fig. 11. Various groundwater arsenic removal principles (BGS/MML 1999a).

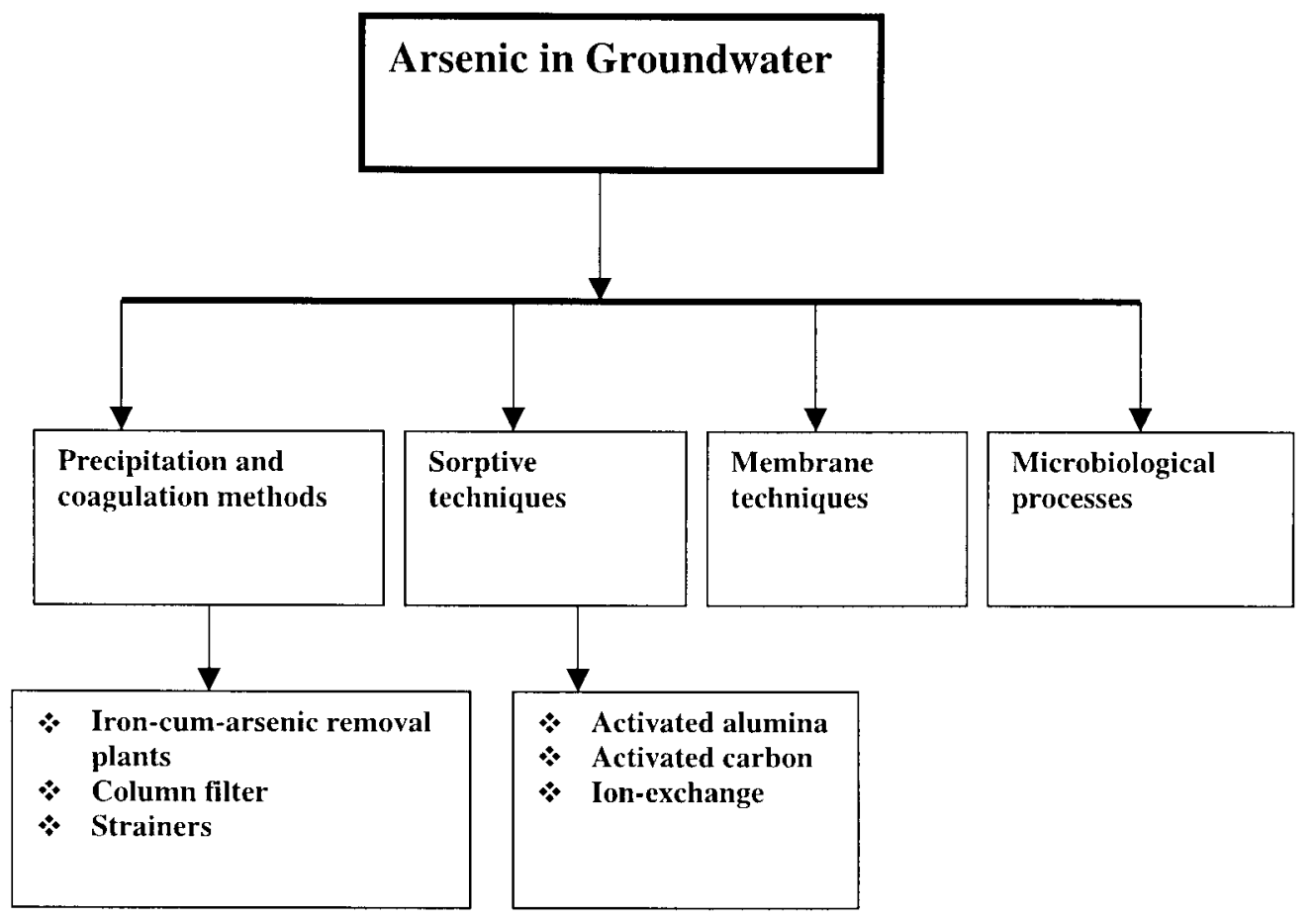

Fig. 12. Amount of arsenic adsorbed on laterite (in percent) from contaminated groundwaters of BDP (modified from Larsson et al. 1997). Results shown above are based on three batch tests where $100 \mathrm{~mL}$ contaminated groundwater $\left(\mathrm{As}_{101}=334 \mu \mathrm{g} \mathrm{L}^{-1}\right)$ was treated with different amounts of laterite. The bars $( \pm 5 \%)$ represent the range of variability for arsenic adsorption in the batch tests.

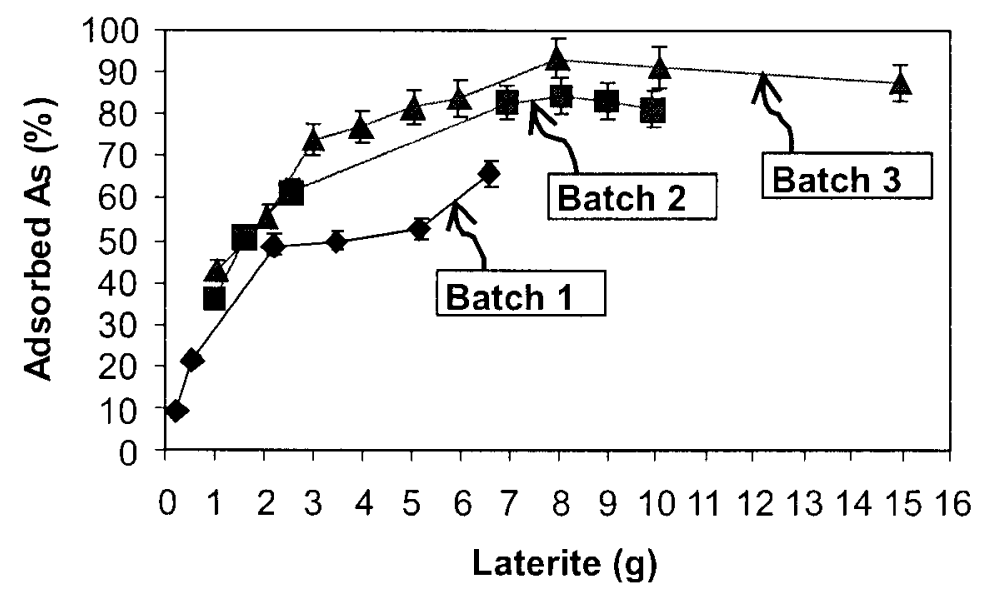

On the other hand, a group of engineers from the Bengal Engineering College, Howrah, West Bengal, India, have developed a unit completely manually operated and not requiring electricity for handwells and hand pumps. Arsenic removal columns are installed at the tubewells using activated alumina. Once every 4 months the regeneration of the unit with caustic soda is necessary. Each unit costs about US\$1250 and can supply arsenic free water for 200 to 300 households. Lifetime of the units, without any maintenance, is about 10 years, and the arsenic-containing sludge can be stored in a pit $(121 \times 121 \times 121 \mathrm{~cm})$ for minimal 8 to 10 years (Anon $2000 b)$. 
Table 7. Concentration of metals in test run groundwater samples from Bangladesh before and after filtration by 3-pitcher filtration method (Khan et al. 2000)

\begin{tabular}{lcc}
\hline Elements & Before filtration $\left(\mathrm{mg} \mathrm{L}^{-1}\right)$ & After filtration $\left(\mathrm{mg} \mathrm{L}^{-1}\right)$ \\
\hline Aluminum & $0.031 \pm 0.022$ & $0.023 \pm 0.011$ \\
Antimony & $<0.013$ & $<0.013$ \\
Arsenic & $\mathbf{0 . 1 3 0}-\mathbf{1 . 1 6}$ & $<\mathbf{0 . 0 1 6}$ \\
Barium & $0.166 \pm 0.006$ & $0.063 \pm 0.01$ \\
Beryllium & $<0.001$ & $<0.001$ \\
Cadmium & $<0.001$ & $<0.001$ \\
Calcium & $113 \pm 2.5$ & $59.1 \pm 7.5$ \\
Chromium & $<0.002$ & $<0.002$ \\
Cobalt & $<0.002$ & $<0.002$ \\
Copper & $0.008 \pm 0.001$ & $0.005 \pm 0.002$ \\
Iron & $6.897 \pm 0.110$ & $0.084 \pm 0.002$ \\
Lead & 0.005 & $0.006 \pm 0.002$ \\
Magnesium & $21.67 \pm 0.55$ & $23.17 \pm 3.29$ \\
Manganese & $0.723 \pm 0.017$ & $<0.001$ \\
Molybdenum & $0.002 \pm 0.001$ & $0.003 \pm 0.001$ \\
Nickel & $<0.002$ & $<0.002$ \\
Potassium & $2.23 \pm 0.23$ & $6.71 \pm 1.31$ \\
Selenium & $<0.012$ & $<0.012$ \\
Silver & $<0.002$ & $<0.002$ \\
Sodium & $19.5 \pm 1.14$ & $26.7 \pm 3.15$ \\
Strontium & $0.287 \pm 0.01$ & $0.164 \pm 0.02$ \\
Thallium & $<0.067$ & $<0.067$ \\
Tin & $0.006 \pm 0.004$ & $0.011 \pm 0.008$ \\
Vanadium & $<0.001$ & $0.006 \pm 0.003$ \\
Zinc & $0.08 \pm 0.11$ & $0.009 \pm 0.002$ \\
\hline
\end{tabular}

Besides the above-mentioned developments, Khan et al. (2000) claimed that it is possible to reduce total inorganic arsenic and As(III) concentration below the detection limit of 2 and $10 \mu \mathrm{g} \mathrm{L}^{-1}$, respectively, by using simple local ingredients such as coarse and fine sand, wood charcoal, and iron chips. The whole process is based on filtration and it is known as the "3-pitcher (locally known as 3-kalshi) water purification method". Table 7 indicates the water quality after using this purification method. The authors believe that this is a cost-effective filtration method for removal of arsenic from contaminated groundwater. The process can be further developed by increasing the flow rate of water, but $6.2 \mathrm{~L} \mathrm{~h}^{-1}$ is sufficient for a middle size family of $4-5$ persons.

\section{Conclusions}

For thousand of years, groundwater has served as a unique and reliable source of potable water in developed as well as developing countries. In spite of enormous resources of water from surface and sizable precipitation in Bangladesh, the country has faced tremendous shortage of drinking water due to the risks of microbial contamination in surface water. Exploitation of groundwater resources started in Bangladesh during the 1960s and has increased dramatically in the past three decades to reach a goal for providing safe drinking water to nearly $97 \%$ of the rural population. Moreover, use of groundwater was also promoted to support wetland cultivation in the region. In 1993, arsenic was detected in groundwater at elevated concentrations ( $>50 \mu \mathrm{g} \mathrm{L}^{-1}$ ), which has posed a serious threat to public health. Use of arsenic-contaminated groundwater in irrigation has, moreover, resulted in bioaccumulation of arsenic in crops and vegetables grown in the region. 
Inorganic arsenic enters the ecosystem by natural and anthropogenic sources. Data on industrial emissions of arsenic to the atmosphere in Bangladesh are scare, although a high concentration of arsenic $\left(5000 \mathrm{mg} \mathrm{kg}^{-1}\right)$ has been reported in the soil in the vicinity of some industrial facilities. However, causes of groundwater arsenic contamination arising from anthropogenic sources is not applicable for such a wide-scale arsenic problem in the Holocene aquifers of the BDP. Arsenic concentration in groundwater of the BDP is by and large prevalent from the Holocene sedimentary aquifers. Wells placed at the shallow aquifers ( $>10-150 \mathrm{~m}$ ) mostly yield water with high arsenic concentration, but the concentration of arsenic is found to decrease with depth. This observation is, however, quite inadequate for generalization, as factors controlling the mobilization of arsenic at the sediment-water interface are dependent on the lithological and biogeochemical constraints of the aquifers. Arsenic concentration in groundwater varies by and large between $>50$ and $1000 \mu \mathrm{g} \mathrm{L}^{-1}$, but still higher values were measured in different studies from isolated areas of the BDP. The present study suggests that arsenic concentration in groundwater is related to mobilization of arsenic from the aquifers sediments driven primarily by the reductive dissolution of the surface-reactive inorganic phases such as $\mathrm{Fe}-, \mathrm{Mn}-$, and Al-oxyhydroxides in the sediments.

Hydrogeochemical studies indicate that the groundwaters are circum-neutral $(\mathrm{pH} \mathrm{6.5-7.6) \text {with }}$ moderately to strongly reducing character ( $\mathrm{Eh} 594$ to $-444 \mathrm{mV}$ ). Major ion chemistry is dominated by $\mathrm{HCO}_{3}, \mathrm{Ca}$, and $\mathrm{Mg}$. Dissolved organic carbon and phosphate concentrations in groundwater are high. $\mathrm{SO}_{4}$ and $\mathrm{NO}_{3}$ concentrations are significantly low and consistent with the high levels of dissolved $\mathrm{Fe}_{\text {tot }}$ and $\mathrm{As}_{\text {tot }} . \mathrm{HCO}_{3}$ was found to be correlated with both $\mathrm{Fe}_{\text {tot }}$ as well as the DOC. Aqueous speciation of As is dominated by the trivalent species and confirms the reducing character of the BDP groundwaters. Elevated concentration of arsenic is found in the aquifer sediments at different locations and depth varies between 5 and $294 \mathrm{mg} \mathrm{kg}^{-1}$. We have also observed positive correlation between $\mathrm{As}_{\mathrm{NO}_{3}}$ and $\mathrm{Fe}_{\mathrm{NO}_{3}}$ $(p<0.001)$, whereas weak correlation was noted for $\mathrm{As}_{\mathrm{NO}_{3}}$ and $\mathrm{P}_{\mathrm{NO}_{3}}(p<0.05)$. The sediments contain amorphous $\mathrm{Fe}-, \mathrm{Mn}-$, and $\mathrm{Al}$-oxyhydroxides revealed by the oxalate extractable $\mathrm{Fe}\left(\mathrm{Fe}_{\mathrm{ox}}=4.2-\right.$ $\left.174 \mathrm{mg} \mathrm{kg}{ }^{-1}\right), \mathrm{Mn}\left(\mathrm{Mn}_{\mathrm{ox}}=0.1-4.5 \mathrm{mg} \mathrm{kg}{ }^{-1}\right)$, and $\mathrm{Al}\left(\mathrm{Al}_{\mathrm{ox}}=0.643 .7 \mathrm{mg} \mathrm{kg}^{-1}\right)$, which accounts for the bulk of the oxalate extractable As. The mechanisms of arsenic mobilization in BDP groundwater are governed by the microbial reduction of Fe- and Mn-oxyhydroxides under anoxic conditions. Further studies are required to understand these complex biogeochemical interactions in the reducing BDP aquifers and their role in arsenic mobilization.

Arsenic enters humans via air, water, and food. High concentration of arsenic in drinking water and the food chain has caused severe health problems in rural areas of Bangladesh, especially in southern Bangladesh. The toxic character of arsenic has been known for centuries. A dose-response relationship between inorganic arsenic exposure from pumped groundwater and skin disorders (keratosis), internal cancer, respiratory, and cardiovascular problems has been established not only in Bangladesh but also for many other countries. Clinical manifestations of arsenic toxicity have also created severe social problems.

Keeping in view the poor infrastructure of the country, it is necessary to seek techniques of low-cost arsenic removal from groundwater suitable for drinking purposes in rural areas. Natural geological material such as laterite has shown promising results with an arsenic removal efficiency of $70-90 \%$. In some areas, local materials such as coarse sand, wood charcoal, and iron filings have also been used for the removal of arsenic from drinking water. However, this is the largest single groundwater arsenic problem occurring so far in modern civilization, and it deserves special attention as well as international programs on drinking water issues.

\section{Acknowledgments}

PB acknowledges financial grants received from the Swedish International Development Agency (Sida-SAREC) and the Swedish Natural Science Research Council (NFR) for the studies on the higharsenic groundwater in Bangladesh. We are thankful to Ann Fylkner at the Division of Land and Water 
Resources and Monica Löwen at the Division of Water Resources Engineering, Royal Institute of Technology, for the ion analyses and Lena Lundman at Tema Vatten, Linköping University, for trace element analyses. Gunnar Jacks and B.J. Skinner provided constructive criticisms of the previous draft of the manuscript. Many thanks to Alok Nandi (Commediastra, Brussles) for French translation, and language was corrected by Ken Himsworth, for which ABM is grateful. ABM also acknowledges with thanks the assistance received in preparation of this manuscript from the staff members of the Department of Limnology and Environmental Protection, University of Helsinki. Finally, we are grateful to the anonymous reviewers for their thoughtful comments.

\section{References}

Acharyya, S.K., Chakraborty, P., Lahiri, S., Raymahashay, B.C., Guha, S., and Bhowmik, A., 1999. Arsenic poisoning in the Ganges Delta. Nature, 401: 545.

Ahmed, K.M. 1999. A review of available geochemical data and their implications to the origin of arsenic in Bangladesh groundwater. KTH-Dhaka University seminar on groundwater arsenic contamination in the Bengal Delta Plains of Bangladesh. Department of Geology, University of Dhaka, Dhaka 1000, Bangladesh. February 7-8, 1999. 24 p.

Anon. 2000a. Available from http://www.unicefusa.org/alert/emergency/bangladesh/bangladesh.html [accessed 2 October 2001].

Anon. 2000b. Available from http://www.lehigh.edu/pamd/arsenic.html.

Armienta, M.A., Rodriguez, R., Aguayo, A., Ceniceros, N., Juraez, F., Cruz, O., and Villasenor, G. 1995. Point and regional sources of arsenic in the groundwater of Zimpan, Mexico. Acta Univ. Carol. Geol. 39 : 285-290.

Armienta, M.A., Rodriguez, R., Aguayo, A., Ceniceros, N., Villaseñor, G., and Cruz, O. 1997. Arsenic contamination of groundwater at Zimapán, México. Hydrogeol. J. 5: 39-46.

Armienta, M., Brust, H., Rodriguez, R., Ongley, L.K., Ceneccros, N., Aguayo, A., and Cruz, O. 2000. Cleanwater alternatives to arsenic naturally polluted groundwater in semi-arid zone of Mexico. In Arsenic in groundwater of sedimentary aquifers. Edited by P. Bhattacharya and A.H. Welch. Pre-Congress Workshop Abstract Volume, 31 st International Gcological Congress, Rio de Janeiro, Brazil. pp. 12-14. Available from http://amov.ce.kth.se/PEOPLE/Prosun/Rio_abstract.pdf [accessed 2 October 2001].

Arnold, H.L., Odman, R.B., and James, W.D. 1990. In Disease of the skin clinical dermatology. W.B. Saunders Co., Philadelphia, Pa. pp. 121-122.

ATSDR. 1993. Toxicological profile for arsenic. U.S. Dept of Health \& Human Services, Agency for Toxic Substances and Disease Registry, TP-92/02: 102-123.

Bagla, P., and Kaiser, J. 1996. India's spreading health crisis draws global arsenic experts. Science, 274: 174-175.

Bangladesh Agriculture Sector Review. 1989. Main Report - Bangladesh agriculture: Policies and performance, United Nations Development Program, Dhaka.

Baurne, G. 1999. Bangladesh - Land of rivers. A mission report on water resources in Bangladesh. Department of Civil and Environmental Engineering, Royal Institute of Technology, Stockholm, Sweden. $82 \mathrm{p}$.

Bhattacharya, P., and Jacks, G. 2000. Arsenic contamination in groundwater of the sedimentary aquifers in the Bengal Delta Plains: A review. In Arsenic in groundwater of sedimentary aquifers. Edited by P. Bhattacharya and A.H. Welch. Pre-Congress Workshop Abstract Volume, 31 st International Geological Congress, Rio de Janciro, Brazil. pp. 19-21. Available from http://amov.ce.kth.se/PEOPLE/Prosun/Rio_abstract.pdf [accessed 2 October 2001].

Bhattacharya, P., and Mukherjec, A.B. 2000. Global scarcity of groundwater with special reference to the conflicting issues on arsenic contamination in Bengal Delta Plain. In Conflicting management of water resources. Edited by M. Chatterji, S. Arlosoroff, and G. Guha, New York, N.Y. In press.

Bhattacharya, P., Chatterjee, D., and Jacks, D. 1996. Options to safeguard groundwater from arseniferous aquifers in West Bengal, India. In Reaching the Unreached-Challenges for the 21 st Century. Edited by J. Pickford, S. House, D. Miles, J. Ockelford, J. Parr, D. Saywell, R. Shaw, B. Skinner, I. Smout, and 
R. Stear. Proceedings of the 22nd WEDC Conference, New Delhi, India. University of Loughborough. pp. 258-261.

Bhattacharya, P., Chatterjee, D., and Jacks, G. 1997. Occurrence of As-contaminated groundwater in alluvial aquifers from the Delta Plains, Eastern India: Options for safe drinking water supply. Water Resour. Develop. 13: 79-92.

Bhattacharya, P., Larsson, M., Leiss, A., Jacks, G., Sracek, A., and Chatterjee, D. 1998a. Genesis of arseniferous groundwater in the alluvial aquifers of Bengal Delta Plains and strategies for low-cost remediation, Abstract Volume, International Conference on Arsenic Pollution of Groundwater in Bangladesh: Causes, effects and remedies. Dhaka, Bangladesh. pp. 120-123.

Bhattacharya, P., Sracek, A., and Jacks, G.1998b. Groundwater arsenic in Bengal Delta Plains - Testing of Hypothesis. Abstract, International Conference on Arsenic Pollution of Groundwater in Bangladesh; Causes, Effects and Remedies, Dhaka, Bangladesh. West Bengal and Bangladesh Arsenic Crisis Information Center. Http://bicn.com/acic/infobank/bp2.htm.

Bhattachrya, P., Jacks, G., Gustafsson, J.P., Sracek, A., Olofsson, B., Aaltonen, J., Khan, A.A., Akhter, S.H., and Ahmed, K.M. 1999a. High-arsenic groundwater in the alluvial aquifers of Bengal Delta Plains in Bangladesh: Genesis and low-cost remediation. KTH - Dhaka University Seminar on Groundwater Arsenic Contamination in the Bengal Delta Plains of Bangladesh, February 7-8, 1999. pp. 6-9.

Bhattacharya, P., Ahmed, K.M., Hasan, M.A., Jacks, G., Khan, A.A., Akhter, S.H., Imam, M.B., and Sracek, A. $1999 \mathrm{~b}$. Groundwater arsenic in the Holocene alluvial aquifers of Bengal Delta Plains: Petrological, geochemical and isotope geochemical studies. International Conference on Arsenic in Bangladesh Ground Water: World's Greatest Arsenic Calamity. Wagner College, New York, N.Y., February 27-28, 1999.

Bhattacharya, P., Jacks, G., Larsson, M., Leiss, A., Bhattacharyya, R., Chatterjee, D., and Brömssen, M. von. 2000. Suitability of low-cost remediation techniques for the amendment of high-arsenic groundwater in West Bengal and Bangladesh. Abstract, International Workshop on Control of Arsenic Concentration in Groundwater, PHED, Calcutta, January 5-6, 2000. pp. 33-33a.

Bhattacharya, P., Jacks, G., Sracek, A., Gustafsson, J.P., and Chatterjee, D. 2001. Geochemistry of the Holocene alluvial sediments in the Bengal Delta Plains: Implication on arsenic contamination in the groundwater. In Proceedings of the KTH - Dhaka University Seminar on Groundwater Arsenic Contamination in the Bengal Delta Plains of Bangladesh. Edited by G. Jacks, P. Bhattacharya, and A.A. Khan. KTH Special Publication, Stockholm, Sweden. TRITA-AMI report 3084.

Biswas, B.K., Dhar, R.K,. Samanta, G., Mandal, B.K., Chakraborti, D., Faruk, I., Islam, K.S., Chowdhury, Md. M., Islam, A., and Roy, S. 1998. Detailed study report of Samta, one of the arsenic-affected villages of Jessore District, Bangladesh. Curr. Sci. 74(2): 134-145.

Black, M. 1990. From hand pumps to health. UNICEF, New York: $133 \mathrm{p}$

Borgoño, J.M., and Greiber, R. 1972. Epidemiological study of arsenicism in the city of Antofagasta. In Trace substances in environmental health - V.A. Symposium, Edited by D.D. Hemphill. University of Missouri Press, Columbia, Mo. pp. 13-24.

Borgoño, J.M., Vicent, P., Venturino, H., and Infante, H. 1977. Arsenic in the drinking water of the city of Antofagasta: epidemiological and clinical study before and after the installation of a treatment plant. Environ. Health Perspect. 19: 103-105.

British Geological Survey/Mott MacDonald Ltd. (UK) (BGS/MML). 1999a. Arsenic contamination of groundwater in Bangladesh: A review. Prepared for: Department of Public Health Engineering, Goverment of Bangladesh, Dhaka. S5. 54 p.

British Geological Survey/Mott MacDonald Ltd (UK) (BGS/MML). 1999b. Groundwater studies for arsenic contamination in Bangladesh: Final report. Prepared for: Department of Public Health Engineering, Goverment of Bangladesh. Phase 1. pp. 1.1-7.7.

Buchet, J.P., Lauwerys, R., and Roels, H. 1980. Comparison of several methods for the determination of arsenic compounds in water and urine. Their application for the study of arsenic metabolism and for the monitoring of workers exposed to arsenic. Int. Arch. Occup. Environ. Health, 46: 11-29.

Bundschuh, J., Bonorino, G., Viero, A.P., Albouy, R., and Fuertes, A. 2000. Arsenic and other trace clements in sedimentary aquifers in the Chaco-Pampean Plain, Argentina: Origin, distribution, speciation, social and economic consequences. In Arsenic in groundwater of sedimentary aquifers. Edited By P. Bhattacharya and A.H. Welch. Pre-Congress Workshop Abstract Volume, 31 st International Geological Congress, Rio de 
Janeiro, Brazil. pp. 27-32. Available from http://amov.ce.kth.se/PEOPLE/Prosun/Rio_abstract.pdf [accessed 2 October 2001].

Chakraborty, A.K., and Saha, K.C. 1987. Arsenical dermatosis from tube well water in West Bengal. Ind. J. Med. Res. 85: 326-334.

Chatterjee, A., Das, D., Mandal, B.K., Chowdhury, T.R., Samanta, G., and Chakraborti, D. 1995. Arsenic in groundwater in six districts of West Bengal, India: The biggest arsenic calamity in the world. Part $\mathrm{I}$. Arsenic species in drinking water and urine of the affected people. Analyst, 120: 643-650.

Cebrian, M.E., Albores, A., Aquilar, M., and Blakely, E. 1983. Chronic arsenic poisoning in the north of Mexico. Hum. Toxicol. 2: 121-133.

Chen, C.Y., and Folt, C.L. 2000. Bioaccumulation and diminution of arsenic and lead in a freshwater food web. Env. Sci. Technol. 34(18): 3878-3884.

Chen, S.L., Dzeng, S.R., Yang, M.H., Chiu, K.H., Shieh, G.M., and Wai, C.M. 1994. Arsenic species in groundwaters of the Blackffot disease area, Taiwan. Env. Sci. Technol. 28: 877-881.

Choprapawon, C., and Rodcline, A. 1997. Chronic arsenic poisoning in Ronphibool Nakhon Sri Thammarat, the Southern province of Thailand. In Arsenic exposure and health effects, Edited by C.O. Abernathy, R.L. Calderon, and W.R. Chappell. Chapman and Hall. pp. 69-77.

Chowdhury, N.I., Ahmed, M.F., and Chowdhury, J.R. 1987. Use of rainwater for water supply in coastal areas of Bangladesh, Proceedings of the International Conference on Rain Water Cistern System, Thailand, January 14-17.

Chowdhury, U.K., Biswas, B.K., Dhar, R.K., Samanta, G., Mandal, B.K., Roy Chowdhury, T., Chakraborti, D., Kabir, S., and Roy, S. 1999. Groundwater arsenic contamination and suffering of people in Bangladesh. In Arsenic exposure and health effects. Edited by W.R. Chappell, C.O. Abemathy, and R.L. Calderon. Elsevier Science B.V., U.K. pp. 165-182

Clarke, L.B., and Sloss, L.L. 1992. Trace elements - Emissions from coal combustion and gasification. IEA Coal Research, London, U.K. IEACR/49. $111 \mathrm{p}$.

Dainichi Consultant, Inc. 1999. http://www.dainichi-consul.co.jp/english/arsenic/arsstat.htm.

Das, D., Samanta, G., Mandal, B.K., Roy Chowdhury, T., Chanda, C.R., Chowdhury, P.P., Bose, G.K., and Chakraborti, D. 1996. Arsenic in groundwater in six districts of West Bengal, India. Environ. Geochem. Health, 18: 5-15.

Dhar, R.K., Biswas, B.K., Samanta, G., Mandal, B.K., Chakraborti, D., Roy, S., Jafar, A., Islam, A., Ara, G., Kabir, S., Khan, A.W, Ahmed, S.A., and Hadi, S.A. 1997. Groundwater arsenic calamity in Bangladesh. Curr. Sci. 73(1): 48-59.

Dhaka Community Hospital (DCH). 1997. Dhaka Community Hospital Trust, Monthly Newsletter, January 1997.

Dhaka Community Hospital (DCH). 1998. Dhaka Community Hospital. International Conference on arsenic pollution of groundwater in Bangladesh: Causes, effects and remedies. Dhaka Community Hospital, Dhaka, Bangladesh.

FAO/WHO. 1998. Committee on Food Additives and Contaminants. 31 st Season, Poison paper on arsenic.CX/FAC 99/22, Alimentarius Commission, Rome: Joint FAO/WHO Food Standard Programme.

Farmer, J.G., and Johnson, L.R. 1990. Assessment of occupational exposure to inorganic arsenic based on urinary concentrations and speciation of arsenic. Br. J. Ind. Med. 42: 342-348.

Ferguson, J.F., Gavis, J. 1972. A review of the arsenic cycle in natural waters. Water Res. 6: 1259-1274.

Gottschalk, C., Schmitz, S., Drichaus, W., and Jekel, M. 1992. Verfahren zur oxidation von arsenate (III) in trinkwasseraufbereitung. Vom Wasser. 79: 225-235.

Grantham, D.A., and Jones, F.J. 1977. Arsenic contamination of water wells in Nova Scotia. J. Am. Water Works Assoc. 69: 653-657.

Guha Mazumder, D.N., Chakraborty, A.K., Ghosh, A., Gupta, J.D., Chakraborty, D.P., Dey S.B., and Chattopadhyay, N. 1988. Chronic arsenic toxicity from drinking tubewell water in rural West Bengal. Bull WHO, 66: 499-506.

Guha Mazumder, D.N., Gupta, J.D., Chakraborty, A.K., Chatterjee, A., Das, D., and Chakraborti, D. 1992. Environmental pollution and chronic arsenicosis in South Calcutta. Bull. WHO, 70: 481-485.

Hamid, M.A. 1993. Improving the access of the rural poor to groundwater irrigation in Bangladesh. In Groundwater irrigation and the rural poor: Options for development in the Gangetic Basin. Edited by F. Kahnert and G. Levine. The World Bank, Washington, D.C. pp. 61-72. 
Huq, S., and Rahaman, A.A. 1994. An environmental profile of Bangladesh. In Environment and development in Bangladesh. Edited by A.A. Rahaman, R. Haider, S. Huq, and E.G. Jansen, University Press Limited, Dhaka, Bangladesh. Vol 1. pp. 38-95.

Huq, S.M.I., Ara, Q.A.J., Islam, K., Zaher, A., and Naidu, R. 2001. Possible contamination from arsenic through food chain. In Proceedings of the KTH - Dhaka University Seminar on Groundwater Arsenic Contamination in the Bengal Delta Plains of Bangladesh. Edited by G. Jacks, P. Bhattacharya, and A.A. Khan, KTH Special Publication, Stockholm, Sweden. TRITA-AMI report 3084.

Idman, H. 1996. Luonnollisen arseenipitoisuuden vaihtelu pohjavesiss ä ja siihen vaikuttavat tekijät. In Ympäristögeologian sovelluksia. Edited by T. Nystén, T. Suokko and T. Tarvainen. GTK-SYKE ympäristötutkimusseminaari 1.10.1996. Helsinki, Finnish Environment Institute: pp. 17-22. (In Finnish.)

Jacks, G., and Bhattacharya, P. 1998. Arsenic contamination in the environment due to the use of CCA-wood preservatives. In Arsenic in wood preservatives, Part I. Exemption substances.

Kabata-Pendais, A., and Pendais, H. (Editors). 1992. Trace elements in soils and plants, 2nd ed. CRC Press, Boca Raton, Fla. 203 p.

Karim, Md. M. 2000. Arsenic in groundwater and health problem in Bangladesh. Water Res. 34(1): 304-310.

Khan, A.H. 1994. Environmental aspects of surface water development projects in Bangladesh. In Environment and Development in Bangladesh, Edited by A.A. Rahaman, R. Haider, S. Huq, and E.G. Jansen. University Press Ltd. Dhaka, Bangladesh. Vol. II. pp. 102-130.

Khan, A.H., Rasul, S.B., Munir, A.K.M., Habibuddowla, M., Alauddin, M., Newaz, S.S., and Hussam, A. 2000. Appraisal of a simple arsenic removal method of Bangladesh. J. Environ. Sci. Health, Part A, 35(7): $1021-1041$

Korte, N.E., and Fernando, Q. 1991. A review of arsenic (III) in ground-water. Crit. Rev. Environ. Control, 21(1): 1-39

Lai, M.S., Hsueh, Y.M., Chen, C.J., Shyu, M.P., Chen, S.Y., Wu, M.M., Kuo, T.L., and Tai, T.Y. 1994. Ingested inorganic arsenic and prevalence of diabetes mellitus. Am. J. Epidemiol. 139: 484-492.

Langner, H.W., and Inskeep, W.P. 2000. Microbial reduction of arsenate in the presence of ferrihydrite. Environ. Sci. Technol. 34: 3131-3136.

Larsson, M., and Leiss, A. 1997. Arsenic in groundwater in Nadia district, West Bengal, India. M.Sc. thesis, Royal Institute of Technology, Stockholm, Sweden. 43 p.

Larsson, M., Leiss, A., Bhattacharya, P., Jacks, G., and Chatterjec, D. 1999. High-arsenic groundwater in West Bengal, India: Test of laterite as a filter media. Nord. Soc. Clay Res., Medd. 12: 12-14.

Lawrence, J.F., Michalik, P., Tam, G., and Conacher, H.B.S. 1986. Identification of arsenobetaine and arsenocholine in Canadian fish and shellfish by high-performance liquid chromatography with atomic absorption detection and conformation by fast atom bombardment mass spectrometry. J. Agric. Food Chem. 34(2): 315-319.

Lianfang, W., and Jianzhong, H. 1994. Chronic arsenicism from drinking water in some areas of Xinjiang, China. In Arsenic in the environment, Part II: Human health and ecosystem effects. Edited by J. Nriagu. John Wiley Inc. New York, N.Y. pp. 159-172.

Liukkonen-Lilja, H. 1993. Arseeni elintarvikkeissa. Helsinki 1993 (Arsenic in foods, Helsinki 1993). National Food Administration Research Notes 12, Helsinki, Finland. 16 p. (In Finnish.)

Lu, F.J. 1990. Blackfoot disease: Arsenic or humic acid? Lancet, 336: 115.

Lunde, G. 1973. Separation and analysis of organic-bound and inorganic arsenic in marine organisms. J. Sci. Food Agric. 24: 1021-1027.

L.uo, Z.D., Zhang, Y.M., Ma, L., Zhang, G.Y., He, X., Wilson, R., Byrd, D.M., Griffiths, J.G., Lai, Lai, S., He, L., Grumski, K., and Lamm, S.H. 1997. Chronic arsenicism and cancer in Inner Mongolia: Consequences of well-water levels greater than $50 \mu \mathrm{g} / \mathrm{l}$. Http://phy4.harvard.edu/ wilson/inner_mongolia_paper1.html.

Mandal, B.K., Roy Chowdhury, T., Samanta, G., Basu, G.K., Chowdhury, P.P., Chanda, C.R., Lodhi, D., Karan, N.K., Dhar, R.K., Tamili, D.K., Das, D., Saha, K.C., and Chakraborti, D. 1996. Arsenic in groundwater in seven districts of West Bengal, India: The biggest arsenic calamity in the world. Curr. Sci. 70(11): 976-986.

Mazumdar, M.L. 2000. Groundwater arsenic contamination in Bangladesh: Hydrogeochemical studies at Tala Thana in Satkhira District, Southwestern Bangladesh. M.Sc. thesis. Royal Institute of Technology, Stockholm, Sweden. 
Morton, W.E., and Dunnette, D.A. 1994. Health effects of environmental arsenic. In Arsenic in the cnvironment, Vol II. Edited by J.O. Nriagu. John Wiley \& Sons, Inc., New York, N.Y. pp. 17-34

National Academy of Sciences (NAS). 1977. Medical and biologic effects of environmental pollutants: arsenic. National Academy of Sciences, Washington, D.C.

Nickson, R.T., McArthur, J.M., Burgess, W.G., Ahmed, K.M., Ravenscroft, P., and Rahaman, M. 1998. Arsenic poisoning of Bangladesh groundwater. Nature, 395: 338.

Nickson, R.T., McArthur, J.M., Ravenscroft, P., Burgess, W.G., and Ahmed, K.M. 2000. Mechanism of arsenic release to groundwater, Bangladesh and West Bengal. Appl. Geochem. 15: 403-413.

Nriagu, J.O. 1989. Natural sources of trace metal emission to the atmosphere: global assessment. Nature, 338: 47-49.

Nriagu, J.O., and Pacyna, J.M. 1988. Quantitative assessment of worldwide contamination of air, water and soils with trace metals. Nature, 333: 134-139.

Pacyna, J.M. 1996. Atmospheric emissions of heavy metals for Europe. A final report for the International Institute for Applied Systems Analysis, Hagan Monday, January 1996.

Pacyna, J.M. 1998. Source inventories for atmospheric trace metals. In Atmospheric particles. Edited by R.M. Harrison and R. Van Grieken. John Wiley and Sons, New York, N.Y. pp. 385-423.

Pierce, M.L., and Moore, C.M. 1982. Adsorption of arscnite and arsenate on amorphous iron hydroxide. Water Resour. 16: 1247-1253.

Pitman, G.T.K. 1993. National water planning in Bangladesh 1985-2005: The role of groundwater in irrigation development. In Groundwater irrigation and the rural poor: Options for development in the Ganges Basin. Edited by F. Kahnert and G., Levine. The World Bank, Washington, D.C. pp. 31-60.

Pokrovski, G., Gout, R., Schott, J., Zotov, A., and Harrichoury, J.C. 1996. Thermodynamic properties and stoichiometry of $\mathrm{As}(\mathrm{III})$ hydroxide complexes at hydrothermal conditions. Geochim. Cosmochim. Acta, 60(5): 737-749.

Pomroy, C., Charbonneau, S.M., McCullough, R.S., and Tam, G.K.H. 1980. Human retention studies with 74As. Toxicol. Appl. Pharmacol. 53: 550-556.

Public Health Engineering Department (PHED). 1991. Final Report, National Drinking Water Mission Submission Project on arsenic pollution in groundwater in West Bengal. Steering Committee, Arsenic Investigation Project, Public Health Engineering Department, Government of West Bengal, India. 57 p.

Public Health Enginecring Department (PHED). 1993. First phase Action Plan Report on Arsenic Pollution in Groundwater in West Bengal, Arsenic Investigation Project, Government of West Bengal, India. $46 \mathrm{p}$.

Rahman, M., Wingren, G., and Axelson, O. 1996. Diabetes mellitus among Swedish art glass workers: an effect of arsenic exposure? Scand. J. Work, Environ. Health, 22: 146-149.

Rahman, M., Tondel, M., Akthan Ahmad, S.K., and Axelson, O. 1998. Diabetes mellitus associated with arsenic exposure in Bangladesh. Am. J. Epidemiol. 148: 198-203.

Rahman, M., Tondel, M., Akhtar Ahmad, S., Akther Chowdhury, Ireen, Faruquee, M.H., and Axelson, O. 1999. Hypertension and arsenic exposure in Bangladesh. Hypertension, 33: 74-78.

Rasul, S.B., Ahmed, N., Munir, A.K.M., Washe, S., Khaliquzzaman, M., Khan, A.H., and Hussam, A. 1999 Arsenic in Bangladesh groundwater. World's greatest arsenic calamity. International Conference, Wagner College, Staten Island, N.Y. February 27-28.

Reiman, K.U. 1993. Geology of Bangladesh. Gebruder Borntraeger, Berlin-Stutgart.

Robertson, F.N. 1989. Arsenic in groundwater under oxidizing condition, south-west United States. Environ. Geochem. Health, 11(3-4):171-186.

Roy Chowdhury, T., Biswas, B.K., Chowdhury, U.K., Samanta, G., Mandal, B.K., and Chakraborti, D. 1999. Toxicological effects of geogenic contamination with special reference to arsenic. Abstract Volume of Abstracts. 2nd International Conference on Contaminants in the Soil Environment in the Australasia Pacific Region. New Delhi, India, December 12-17. pp. 397-398.

Rodriguez, R., Ramos, J.A., and Armienta, M.A. 2000. Groundwater arsenic variations: The role of local geology and rainfall. In Arsenic in groundwater of sedimentary aquifers. Edited by P. Bhattacharya and A.H. Welch. Pre-Congress Workshop Abstract Volume, 31 st International Geological Congress, Rio de Janeiro, Brazil. pp. 75-77. Available from http://amov.ce.kth.se/PEOPLE/Prosun/Rio_abstract.pdf [accessed 2 October 2001].

Routh, J., Bhattacharya, P., Jacks, G., Ahmed, K.M., Khan, A.A., and Rahman, M. 2000. Arsenic geochemistry of Tala groundwater and sediments from Satkhira Districts, Bangladesh. Abstract H22F-02, 
American Geophysical Union, Fall Meeting, San Francisco, Calif. December 15-19.

Ryaboshapko, A., Ilyin, I., Gusev, A., Afinogenova, O., Berg, T., and Hjellbrekke, A-G. 1999. Monitoring and modelling of lead, cadmium and mercury transboundary transport in the atmosphere of Europe. Joint report EMEP Centres: MSC-E and CCC, Moscow, Russia. EMEP Report \# 3/99. 124 p.

Saha, K.C. 1995. Chronic arsenic dematosis from tubewell water in West Bengal during 1983-87. Indian J. Dermatol. 40: 1-12.

Saha, A.K., and Chakraborti, D. 1995. Geological and geochemical background of the As bearing groundwater occurrences of West Bengal. In Proceedings of the International Conference on Arsenic in Groundwater: Cause, Effect and Remedy, Calcutta, India.

Sahu, S.J., Roy, S., Jana, J., Bhattacharya, R., Chatterjee, D., and Dey Dalal, S.S. 2000. Evidence of iron in arsenic mobilization groundwater of Bengal Delta Plain. In Annual International Conference on heavy metals in the environment, Edited by J. Nriagu. Contribution \# 1024 University of Michigan, School of Public Health, Ann Arbor, Mich. (CD-ROM).

Samanta, G., Mandal, B.K., Chowdhury, T.R., Biswas, B.K., Chowdhury, U.K., Basu, G.K. Chanda, C.R., Lodh, D., Saha, K.C., and Charraborti, D. 1999 Arsenic in groundwater and sufferings of people in eight districts of West Bengal, India. In Proceedings on 5th International Conference on the Biogeochemistry of Trace Elements. Vienna, Austria, July 11-15, 1999. Edited by W.W. Wenzel, D.C. Adriano, B. Alloway, H.E. Doner, C. Keller, N.W. Lepp, M. Mench, R. Naidu, and G.M. Pierzynski. Vol. I. pp. 256-257.

Smedley, P. 1996. Arsenic in rural groundwater in Ghana. J. Afr. Earth Sci. 22(4): 459-470.

Smedley, P., Nocolli, H.B., Barros, A.J., and Tullio, J.O. 1998. Origin and mobility of arsenic in groundwater from the Pampean Plain, Argentina. In Water-rock interaction. Edited by G.B Arehart and J.R. Hulston. A.A. Balkema, Rotterdam. The Netherlands. pp. 275-278.

Smith, R.L., Howes, B.L., and Duff, J.H. 1991. Denitrification in nitrate-contaminated groundwater: Occurrence in steep vertical geochemical gradients. Geochim. Cosmochim. Acta, 55: 1815-1825.

Sracek, A., Bhattacharya, P., Jacks, G., Chatterjee, D., Larsson, M., and Leiss, A. 2000. Groundwater arsenic in the Bengal Delta Plains: A sedimentary geochemical overview. In Proceedings of the International Seminar on Applied Hydrogeochemistry. Edited by A.L. Ramanathan, V. Subramanian, and R. Ramesh. Annamalai University, Chindambaram, India. pp. 47-55.

Taylor, S.R., and McLenan, S.M. 1985. The continental crust: Its composition and evaluation. Blackwell Scientific, London, U.K. 365 p.

Terade, H., Katsuta, K., Sasagawa, T., Saito, H., Fukuchi, S.K., Yokoyama, Y., Hirokawa, S., Watanabe, Y., Hasegawa, K., Oshina, T., and Sekiguchi, T. 1960. Clinical observations of chronic toxicosis by arsenic. Nihon Rinsho, 118: 2394-2403.

Thornton, I. 1999. Arsenic in the global environment: Looking towards the millennium. In Arsenic Exposure and Health Effects. Edited by W.R. Chappell, C.O. Abemathy, and R.L. Calderon. Elsevier Science B.V. pp. $1-8$.

The New Nation, 1996. A Daily Newspaper of Bangladesh, 11 November 1996.

Tondel, M., Rahaman, M., Magnuson, A., Akther Chowdhury, I., Faruquee, H.M., and Akthar Ahmad, S.K. 1999. The relationship of arsenic levels in drinking water and the prevalence rate of skin lesions in Bangladesh. Environ. Health Perspect. 107: 727-729.

Ullah, S.M., Gerzabek, M.H., Mondal, N., Rashid, M.M., and Islam, M. 1999. Heavy metal pollution of soils and water and their transfer into plants in Bangladesh. In 5th International Conference on the Biogeochemistry of Trace Elements, Vienna, Austria, July 11-15, 1999. Edited by W.W., Wenzel, D.C., Adriano, B., Alloway, H.E., Doner, C., Keller, N.W., Lepp, M., Mench, R., Naidu, and G.M., Pierzynski. Vol. I. pp. 260-261.

UN/ECE. 1999. Strategies and policies for air pollution abatement. ECE/EB.AIR/65, UN 1999: pp. 104-105

US EPA. 1982. Arsenic. In Intermedia priority pollutant guidance documents. Washington D.C., U.S. Environmental Protection Agency, Office of Pesticides and Toxic Substances.

Vaessen, H.A., and van Ooik, A. 1989. Speciation of arsenic in Dutch total diets: Methodology and results. Z. Lebensm. Unters. Forsch. 189: 232-235.

Varsanáyi, I., Zsofia, F., and Bartha, A. 1991. Arsenic in drinking water and mortality in Southern Great Plain, Gungary. Environ. Geochem. Health, 13: 14-22.

von Brömssen, M. 1999. Genesis of high arsenic groundwater in the Bengal Delta Plains, West Bengal and Bangladesh. Master's thesis. Royal Institute of Technology, Stockholm, Sweden. 49 p. 
Welch, A.H. 2000. Arsenic in ground water: A perspective from the United States of America. In Arsenic in groundwater of sedimentary aquifers. Edited by P. Bhattacharya, and A.H. Welch. Pre-Congress Workshop, 31 st International Geological Congress, Rio de Janeiro, Brazil. pp. 81-82. Available from http://amov.cc.kth.se/PEOPLE/Prosun/Rio_abstract.pdf [accessed 2 October 2001].

Welch, A.H., Westjohn, D.B., Helsel, D.R., and Wanty, R.B. 2000. Arsenic in groundwater of the United States: Occurrence and geochemistry. Ground Water, 38(4): 589-604.

WHO. 1981. Arsenic. Environmental Health Criteria \# 18, World Health Organization, Geneva, Switzerland $174 \mathrm{p}$.

Yan-Chu, H. 1994. Arsenic distribution in soils. In Arsenic in the environment. Edited by J.O. Nriagu, John Wiley \& Sons, Inc. New York, N.Y. pp. 17-49.

Zehnder, A.J.B. (Editor). 1988. Biology of anacrobic microorganisms. Wiley and Sons Inc, New York, N.Y. $872 \mathrm{p}$. 